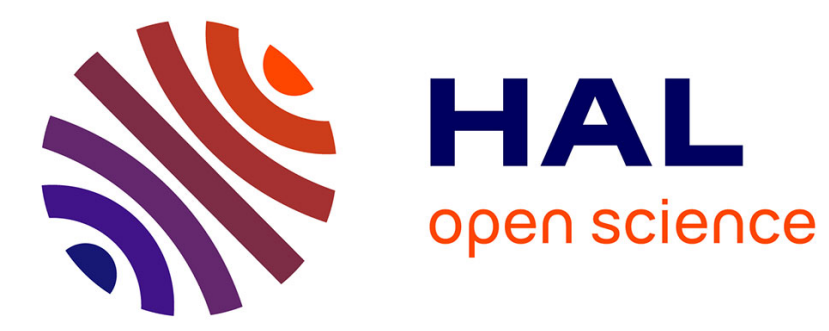

\title{
Bone sarcomas in the immunotherapy era
}

Marie-Françoise Heymann, Kristina K Schiavone, Dominique Heymann

\section{To cite this version:}

Marie-Françoise Heymann, Kristina K Schiavone, Dominique Heymann. Bone sarcomas in the immunotherapy era. British Journal of Pharmacology, 2020, Epub ahead of print. 10.1111/bph.14999 . inserm-02458301

\section{HAL Id: inserm-02458301 https://www.hal.inserm.fr/inserm-02458301}

Submitted on 28 Jan 2020

HAL is a multi-disciplinary open access archive for the deposit and dissemination of scientific research documents, whether they are published or not. The documents may come from teaching and research institutions in France or abroad, or from public or private research centers.
L'archive ouverte pluridisciplinaire HAL, est destinée au dépôt et à la diffusion de documents scientifiques de niveau recherche, publiés ou non, émanant des établissements d'enseignement et de recherche français ou étrangers, des laboratoires publics ou privés. 


\section{Bone sarcomas in the immunotherapy era}

\section{Marie-Françoise Heymann ${ }^{1,2,3}$, Kristina Schiavone ${ }^{1,2}$, Dominique Heymann ${ }^{1,2,3, *}$}

${ }^{1}$ Université de Nantes, INSERM, Institut de Cancérologie de l'Ouest, CRCINA, 44805 Saint Herblain cedex, France.

${ }^{2}$ Institut de Cancérologie de l'Ouest, "Tumor Heterogeneity and Precision Medicine”, Blvd Jacques Monod, 44805 Saint Herblain, France.

3 INSERM, European Associated Laboratory "Sarcoma Research Unit", Department of Oncology and Metabolism, Medical School, University of Sheffield, United Kingdom.

Running title Immunotherapies in bone sarcomas

\section{*Correspondence}

\section{Prof. D. Heymann}

E-mail: dominique.heymann@univ-nantes

\section{Conflict of interest: None}

Keywords: immunotherapy; immune tolerance; immune reprogramming; checkpoint inhibitors; osteosarcoma; chondrosarcoma; Ewing sarcoma 


\section{ABSTRACT}

Bone sarcomas are primary bone tumors which occur mainly in children and adolescents, in the form of osteosarcoma and Ewing sarcoma, and in people in their 40s, in the form of chondrosarcoma. The last four decades have been characterized by the development of therapeutic approaches based on drug combinations, but with no real improvement in overall survival. Recent progress made in the field of oncoimmunology has made it possible to better understand the crucial role played by immune infiltrate in the oncologic process and has led to recent clinical trials with a common aim: reprogramming the immune system in order to facilitate cancer cell recognition. Similarly, immune infiltrates of bone sarcomas have been characterized and the first molecular profiling identified potential immune therapeutic targets, which have been used for designing ongoing clinical trials. Unfortunately, the objective clinical responses in clinical trials remain anecdotal but highlight the necessity to better characterize tumor microenvironment of bone sarcoma to unlock the immunotherapeutic response especially in their pediatric forms. Bone sarcomas have thus entered the immunotherapy era. The present review gives a brief overview of the most recent developments in immunotherapies in bone sarcomas.

\footnotetext{
Abbreviations:

CAR: Chimeric Antigen Receptor: CART T: CAR engineered T-lymphocytes; CTC: Circulating Tumor Cell; CTLA-4: Cytotoxic T-Lymphocyte Associated Protein 4 positive; IL: Interleukin; L-MTP-PE: Liposomal-Muramyl TriPeptide- Phosphatidyl Ethanolamine; MAGE: Melanoma-Associated antiGEn; NK: Natural Killer; NKGD2: Natural Killer Group 2 member D; NY-ESO1: New York ESOphageal squamous cell carcinoma 1; PD-L1: Programmed Death-Ligand 1; TAM: Tumor Associated Macrophages; TIL: Tumor Infiltrating Lymphocytes; TIM-3: T cell Immunoglobulin and Mucin-domain containing-3
} 


\section{Introduction}

With less than $0.2 \%$ of malignant tumors, bone sarcomas are considered to be orphan tumors. These sporadic malignancies are of mesenchymal origin and results from oncogenic and epigenetic events occurring during the differentiation process of mesenchymal stem cells, as well as a permissive microenvironment [Brown et al., 2018]. Bone sarcomas affect preferentially children and young adults, but are not restricted to the young as they can also affect older patients, with incidence depending on histological subtypes [Brown et al., 2018]. The three main common forms of bone sarcoma are osteosarcoma (56\%), Ewing sarcoma (34\%) and chondrosarcoma (6\%), the first two subtypes affecting principally young patients, with a peak of incidence around 18 and 15 years old respectively, while the latter is more common in adults, with a peak of incidence in people in their 40s. Despite their rare incidence, bone sarcomas are characterized by a high mortality rate (e.g. development of lung metastases in osteosarcoma and Ewing sarcoma) and/or morbidity rate (e.g. high risk of local recurrence in chondrosarcoma). Extensive surgical resection with adequate margins in healthy tissues is the central therapeutic procedure for these three tumor entities, combined with adjuvant and neo-adjuvant chemotherapy composed of a cocktail of three drugs (from doxorubicin, cisplatin, methotrexate and ifosfamide) for osteosarcoma, and four drugs for Ewing sarcoma (vincristine, ifosfamide, doxorubicin and etoposide) [Whelan and Davis 2018]. High-grade conventional chondrosarcomas require wide, en-bloc local excision with negative margins and chemotherapy can be proposed for unresectable tumors or recurrent or metastatic disease [Polychronidou et al., 2017; Whelan and Davis 2018]. Unfortunately, despite the aggressive therapeutic arsenal, overall survival, which is around $65 \%$ at 5 years for localized osteosarcoma and Ewing sarcoma and $20-30 \%$ at 5 years for patients with metastases, and 50-60\% at 10 years for chondrosarcoma according the histological subtype 
has not improved in the last four decades and has led to the development of new therapeutic strategies [Heymann et al., 2016].

Immune surveillance is a complex biological process that combines the recognition of tumor cells and by specific effector cells tightly controlled by regulatory immune cells. In turn, tumor cells can secrete soluble factors (e.g. cytokines) to downmodulate the immune surface makers and dampen the immune system. The concept of immunological surveillance was first proposed by Burnet F.M. 50 years ago [Burnet, 1970] and was further refined into the term "cancer immunoediting" [Dunn et al., 2004]. The dual function of immune system in the control of tumor surveillance includes three stages. The first named "elimination" is characterized by the tumor infiltration by innate and adaptative immune cells which eradicate sensitive cancer cells. The second stage is defined by a dynamic "equilibrium" between surviving neoplastic cells and immune infiltrate which exerts a dynamic selective pressure on cancer cells. This selective pressure induces the emergence of cancer-cell subpopulations with specific properties of immune escape or/and immunosuppression and expansion capacity in immunocompetent microenvironment. The immune "escape" is consequently the third stage of the immunoediting is considered to be a hallmark of cancer. The immune system plays then a dual function by slowing down the tumor progression in a first intention and by facilitating the tumor growth after the modeling phase of immunogenic phenotype of tumor cells. Of the potential new targets, the immune environment has received considerable attention and to make an immunotolerant environment in immunocompetent territory is the challenge of immunotherapy for reinducing an antitumoral response. The local immune tolerance results for establishing a permissive microenvironment that is beneficial for cancer cells, have led to the development of new immune-based therapeutic approaches (Figure 1A-C). 
The present review gives a brief overview of the most recent developments in immunotherapies in bone sarcomas focusing on the current state of adoptive cell therapy, immune checkpoint inhibitors or vaccine and drug approaches. The manuscript will describe the disappointing results of the first clinical trials and will underline the promising track proposed for reeducating the immune system into immunocompetent therapeutic tool.

\section{Historical observation leading to ongoing clinical development}

Even imunotherapeutic approaches are still in their early stages in sarcomas, the first evidence of functional immune intervention in sarcomas was reported by Coley, more than 120 years ago. Coley observed complete remission in $10 \%$ of patients after inoculation of heatinactivated Streptococcus pyogenes and Serratia marcescens, known as Coley's toxin. Similar observations were made by Jeys et al. (2007) in osteosarcoma patients with post-operative infection who had higher 10-year survival. This underlined the potential impact of immune system reactivation on the therapeutic response [Miwa et al., 2019]. Immune infiltration is a common feature of bone sarcoma of bone sarcomas and includes T and B lymphocytes, NK cells, polynuclear cells and macrophages [Tellez-Gabriel et al., 2019; Heymann et al., 2019; Withers et al., 2019; Majzner et al., 2017; Palmerini et al., 2017; Simard et al., 2016; Inagaki et al. 2016]. This immune environment in sarcoma seems to play a crucial role in the tumor behavior however its functional evaluation and its value for predicting potential antitumoral response of immunotherapy are in the early stages of investigation [Kelleher and O'Sullivan, 2017; Palmerini et al., 2017; Scott et al., 2018]. Unfortunately, to date, most of clinical trials assessing immunotherapies in soft tissue and bone sarcomas have failed to induce an antitumoral response even if some positive responses have been observed [Tawbi et al., 2017]. The recent disappointing clinical trials with some partial therapeutic response 
demonstrate the necessity to: i) characterize the immune infiltrate in bone sarcoma; ii) understand its incapacity to lead to an efficient ant-tumor response; ii) determine the best strategy to re-induce an immunocompetent environment in bone sarcomas.

\section{Targeting of tumor-associated macrophages in bone sarcomas}

Macrophages and T-lymphocytes are the two main cell populations in the immune landscape of bone sarcomas [Majzner et al., 2017]. Tumor-associated macrophages (TAMs) are very heterogeneous immune effectors, capable of tightly modulating the local immune response, and consequently the death/survival of tumor cells, as well as impacting tumor progression and the metastatic process by acting on angiogenesis (Figure 1B). The concept based on an anti-tumor response triggered by bacterial products such as endotoxins and activating the host's immune cells has been revised in the 1980's. A synthetic analog of a component of the bacterial cell wall (Liposome-encapsulated muramyl tripeptide phosphatidyl ethanolamine or L-MTP-PE, commercialized as Mifamurtide) was produced and assessed in pre-clinical models and clinical trials [Mori et al., 2008; Ando et al., 2011]. Soluble L-MTP-PE binds to the TLR4 receptors expressed at the cell membrane of mononuclear phagocytes and its internalized form is recognized by $\underline{\operatorname{Nod} 2}$ restricted to monocytes, macrophages, dentritic cells, and intestinal Paneth cells which is an intracellular sensor of muramyl dipeptide (MDP) a peptidyl glycan detected in the bacterial wall [Nardin et al., 2006]. The interactions between L-MTP-PE and its receptors result in intracellular signal transduction pathways including NFKB and the MAPK and the secretion of proinflammatory cytokines (e.g. IL-1 $\underline{\beta}, \underline{\text { IL- }}$, $\underline{\text { TNF- }}$ $\underline{\alpha}$, chemokines) driving an inflammatory reaction, dendritic cell recruitment, polarization of T-helper lymphocyte and toxic effects on tumor cells [Ando et al., 2011; Kager et al., 2010; Mori et al., 2008; Nardin et al., 2006]. Independently of Nod2, MDP also triggers a molecular cascade that includes the activation of NLRP3, the cleavage of procaspase-1 into active 
caspase-1 and the activation of proinflammatory cytokines [Marine-Garcia et al., 2008]. LMTP-PE was then assessed in monotherapy and in combination with chemotherapy [Kleinerman et al., 1995; Meyer et al., 2008]. The results issued from the phase III Intergroup-INT0133 trial published by Meyer et al. (2008) showed an improvement of overall survival from 70 to $78 \%(\mathrm{p}=0.03)$ in non-metastatic osteosarcoma when L-MTP-PE was combined with chemotherapy and in a one-third reduction in the risk of death from osteosarcoma. A year after, the analysis of the metastatic cohort did not achieve a statistical improvement in outcome [Chou et al., 2009]. To clarify the potential benefit of mifamurtide which has shown promising effects, a recent phase II clinical trial (Sarcome-13/OS2016, ClinicalTrials.gov, $\mathrm{n}^{\circ} \mathrm{NCT03643133)}$ has been recently set up and plans to evaluate the efficacy of mifamurtide as add-on treatment to post-operative chemotherapy compared to post-operative chemotherapy alone in first-line treatment in metastatic osteosarcoma at the time of diagnosis or localized osteosarcoma with poor histological response [Brad et al., 2019].

As a mirror image of the initial T-lymphocyte classification, the literature has described two main subpopulations of polarized TAMs: M1 with anti-tumor activities and M2-with protumor impact [Noy and Pollard, 2014]. In bone sarcoma, analysis of biological cohorts revealed that M2 macrophagic infiltrate was associated with disease progression in osteosarcoma [Buddingh et al., 2011; Dumars et al, 2016], Ewing sarcoma [Hesketh et al., 2015] and chondrosarcoma [Simard et al., 2016]. The total number of macrophages was associated with good survival, but with a bad prognosis and prevalence of a higher risk of development of lung metastases in patients with the M2 phenotype (a predominance of M2TAMs compared to the M1 subtype) [Buddingh et al., 2011; Dumars et al., 2016]. In a cohort of osteosarcoma samples, Han et al. (2016) studied the correlation between CD163 ${ }^{+}$M2 
subtype and $\underline{\mathrm{TIM}}^{+/-} \underline{\mathrm{PD}}^{+/-}$T-lymphocyte infiltrates. They observed that $\mathrm{TIM}-3^{+} \mathrm{PD}-1^{+} \mathrm{T}-$ lymphocytes infiltrating osteosarcoma tissue exhibited weak proliferation and cytokine responses and were correlated with $\underline{\mathrm{IL}-10}$ and M2-TAM. In this context, $\mathrm{TIM}^{+}{ }^{+} \mathrm{PD}^{+}{ }^{+} \mathrm{T}-$ lymphocytes may be considered as immune suppressive $\mathrm{T}$ cells in osteosarcoma, and they hypothesized the therapeutic benefit of depleted M2-TAMs which would increase T-cell proliferation and release of pro-inflammatory cytokines.

With relation to the functional negative impact of M2-TAMs on bone sarcoma development, drugs modulating macrophage polarization or targeting M2 macrophages are of major therapeutic interest. Among theses drugs, L-MTP-PE in combination with IFN $\underline{\text { may }}$ inhibit osteosarcoma cell proliferation in vitro thanks to its effect on the polarization of M1macrophages independently of their release of IL-1 $\beta$, TNF- $\alpha$ and nitric oxid [Pahl et al., 2014]. In this context, IFN- $\gamma$ may be interesting for optimizing L-MTP-PE activity in osteosarcoma patients. In addition to the M1 macrophage anti-tumor activity, these authors also reported that IL10-polarized M2-like macrophages could show anti-tumor activity against various osteosarcoma cell lines in an antibody-dependent manner and opens new potential immunotherapeutic approaches in osteosarcoma. Trabectedin is an alkylating agent initially extracted from the sea squirt Ecteinascidia turbinata and studied for its anti-tumor activity. Trabectedin induces anti-tumor activities through direct effects on tumor cells and indirect function on the tumor microenvironment. Trabectedin induces single-strand and double-strand DNA breaks, leading to the activation of the DNA damage-response. Consequently, this molecule has cytotoxic effect on cancer cells by inducing a p53 independent cell cycle arrest and also is responsible of macrophage apoptosis [Allavena et al., 2005]. In addition, non-cytotoxic concentrations selectively inhibited the secretion of pro-inflammatory cytokines (e.g. CXCL8, IL-6) by tumor cells [Germano et al., 2010]. More recently, it has been demonstrated that trabectedin 
depleted selectively monocytes and TAM in pre-clinical model of and soft-tissue sarcoma patients [Germano et al., 2013]. M1- and M-2 TAM were similarly affected and this depletion associated mitochondrial depolarization and release of cytochrome $\mathrm{C}$ in the cytosol. The selectivity of trabectine for mononuclear phagocyte versus the other leukocytes could be due to the differential TRAIL signaling [Germano et al., 2013]. Recently, Jones et al. described similar activities in pre-clinical model of prostate cancer [Jones et al., 2019]. In this clinical context, trabectedin targeted $\underline{\mathrm{F} 4 / 80^{+}} \mathrm{CD} 206^{+} \mathrm{M} 2$-TAMs, which were reduced after in vivo exposure to trabectedin and associated with reduced skeletal prostate tumor size.

Because, trabectedin induced DNA inducing single- and double-strand-breaks which can lead to the activation of PARP1, the combination between the combination trabectedin and PARP1 inhibitor has been assessed. In pre-clinical of bone and soft-tissue sarcoma models, trabectedin and PARP1 inhibitors induced a synergistic decrease of tumor development [Grignani et al., 2017]. Unfortunately, in "TOMAS" study (ClinicalTrials.gov, $\mathrm{n}^{\circ}$ NCT02398058), a phase $1 \mathrm{~b}$ clinical trial, the combination of PARP1 inhibitors (Olaparib $100-300 \mathrm{mg}$ twice a day from day 1 to 21$)$ and trabectedin $\left(0.675-1 \cdot 3 \mathrm{mg} / \mathrm{m}^{2}\right.$ every 3 weeks i.v.) was assessed in patients with bone and soft-tissue sarcoma. This combination showed manageable toxicity levels and resulted in encouraging anti-tumor activity in some soft-tissue sarcoma subtypes unfortunately no objective or clinical response was observed in the 11 patients suffering from bone sarcomas enrolled [Grignani et al., 2018]. Very recently, SARC037 (ClinicalTrials.gov, ${ }^{\circ}$ NCT04067115, sponsor: Sarcoma Alliance for Research through Collaboration) is a phase 1 study that aims to evaluate the safety of trabectedin ( $1 \mathrm{mg}$ over 1 hour infusion) combined with irinotecan in Ewing sarcoma. This study planed to enroll 45 patients and did not start to recruit yet. 
Complementary pre-clinical studies underlined the therapeutic benefit of trabectedin. In a patient-derived orthotopic xenograft nude-mouse model, Igarashi et al. (2017) and Higuchi et al. (2019) observed that trabectedin may be able to bypass drug resistance in osteosarcoma. In addition, trabectedin may reprogram the tumor immune environment, making effective use of checkpoint inhibitors possible [Ratti et al., 2017]. Like Mifamurtide or trabectedin, all-trans retinoic acid inhibits in vitro and in in vivo murine model of osteosarcoma the M2 polarization of TAMs [Zhou et al., 2017]. This activity was independent of conventional $\underline{\mathrm{STAT}}, \underline{\mathrm{STAT} 6}$ or $\mathrm{C} / \mathrm{EBP} \beta$ signaling but was associated with the transcriptional regulation of more than 1,200 genes and more specifically by the inhibition of $\underline{\mathrm{IL}-13}$ or $\underline{\mathrm{IL}-4}$ induced M2 polarization. All-trans retinoic acid would prevent the development of lung metastases by downregulating IL13-induced secretion of MMP12. Similarly, dihydroxycoumarins showed antitumor and antimetastatic effect in a murine osteosarcoma model [Kimura and Sumiyoshi, 2015]. The dual effects of these drugs combined a direct effect on cancer cells characterized by a G1 cell cycle phase blockade and an indirect effect by inhibiting the differentiation of M2 macrophages thank the inhibition of IL-10, MCP-1 (CCL2) and TGF- $\beta 1$ secretion [Kimura and Sumiyoshi, 2015]. IL-34 is a twin cytokine of M-CSF sharing the M-CSF receptor and a common macrophage target. This cytokine was detected in osteosarcoma patients [Segaliny et al., 2015]. Drug targeting IL-34 may also represent an interesting therapeutic strategy for preventing osteosarcoma growth/metastasis by inhibiting M2-TAM recruitment mediated by the syndecan-1 [Foucher et al., 2013; Segaliny et al., 2015]. The effect of Il-34 remains controversial and may be dependent of the oncological entities [Lin et al., 2019]. Overall, the data available in the literature demonstrated local intra-tumoral T cellspecific immunosuppression amplified by M2-TAMs and pointed out the potential interest to target specific subset of macrophages or to modulate their polarization. However, as described above even if most of pre-clinical studies published described pre-clinical benefit of 
macrophage targeting in bone sarcomas, clinical trials did not confirm any of these observations in term of overall survival. The high heterogeneity of bone sarcoma cells and immune status of sarcoma tumors accentuates the complexity of a specific targeting of immune cell populations which should be adapted to each patient. Patient stratification must be improved and a better identification/characterization of TAMs (e.g. pro- or anti-tumor subtypes) as well as their correlation with $\mathrm{T}$ cell populations (e.g. $\mathrm{T}$ cell-effectors, modulators, expression of checkpoint molecules) are necessary. Further clinical investigations are then mandatory. In this context, "Micros" clinical trial (ClinicalTrials.gov, $\left.\mathrm{n}^{\circ} \mathrm{NCT} 03737435\right)$ is an observational study which aims to characterize the tumor microenvironment in patients with localized osteosarcoma treated with Mifamurtide. The investigators aim to correlate the level of the PDL-1 checkpoint with event-free survival and overall-survival, and with M1 (anti-tumor macrophages) and M2 (pro-tumor macrophages) (Figure 1B).

\section{Dendritic cells for improving the immune recognition of bone sarcoma cells}

Dendritic cells are heterogeneous entities of antigen presenting cells that infiltrate tumor tissues and exhibit a critical function in the priming and maintenance of local immunity. Dendritic cells are dedicated to the antigen presentation to naïve $\mathrm{T}$ lymphocytes in order to stimulate their differentiation toward professional cancer cell killers and they can also activate $\gamma \delta$ T-lymphocytes with marked antitumour functions [Fiore et al., 2000]. In order to escape to the immune surveillance, tumors most frequently endeavor to moderate the antigen presentation by antigen-presenting cells leading to a local immunosuppression and a defective immune response. Dendritic cell based therapies have been proposed to bypass this process and is designed as dendritic cell vaccines. Neoantigens are tumor-specific antigens not expressed by normal cells. They derive from random somatic mutations and can be 
recognized by the immune system in contrast to non-mutated self-antigens. Unfortunately, the low clonal frequency of neoantigen-specific cytotoxic $\mathrm{T}$ lymphocytes and the inefficient presentation of tumor-associated antigens lead to the defective anti-tumor response. Based on this observation, cancer vaccine or adoptive $\mathrm{T}$ cell therapies have been proposed to potentiate the immune response against these tumor-associated antigens. Bone sarcomas expressed specific antigens (Table 1) which have stimulated the development of targeted therapies. Effective anti-cancer therapies alone or in combination have thus been designed in bone sarcomas to stimulate tumor-associated dendritic cell function as a means of driving the antitumor immune response and preclinical results showed promising results [Li et al., 2019; He et al., 2016; Fang et al., 2015; Kawano et al., 2015]. Clinical investigations did not confirm the results of pre-clinical studies. Indeed, Himoudi et al. (2012) assessed a vaccine therapy based on autologous DCs matured with autologous tumour lysate and keyhole limpet haemocyanin in 12 patients with relapsed osteosarcoma. Patients received 3 weekly vaccines up to 6 vaccinations. The dendritic cell immunotherapy was safe with no apparent toxicity however dendritic cell vaccine therapy was associated a significant anti-tumor response in only 2 out of 12 vaccinated patients with no evidence of clinical benefit. Krishnadas et al. (2015) used dendritic cells pulsed with overlapping peptides derived from full-length MAGEA1, MAGE-A3 and NY-ESO-1 antigen tumors to treat relapsed/refractory solid tumors, including Ewing sarcoma and osteosarcoma (10 patients evaluable aged 2.5 to 15 years with relapsed disease). Four cycles consisted in autologous dendritic cells $\left(10 \mathrm{mg} / \mathrm{m}^{2} /\right.$ day for 5 days week 1 and dendritic cell vaccine once weekly on weeks 2 and 3. The clinical benefit was limited and only one objective response (complete remission) was documented. In 2017, Miwa et al. published the results of a phase 1/2 clinical trial analyzing the therapeutic benefit of autologous dendritic cells pulsed with autologous tumor lysate 37 patients with advanced bone and soft tissue sarcomas. No severe adverse effect was observed and an interesting 
immunological response was detectable as revealed with increased serum levels of IFN $\gamma$ and $\underline{\text { IL-12, }} 4$ weeks after cell injection. However, only one patient showed a partial clinical response, 6 had stable disease and the tumor progressed in 28 patients. An adequate recognition of tumor cells by antigen-specific cytotoxic $\mathrm{T}$ lymphocytes is a prerequisite to obtain an efficient tumor response. In order to evade immune recognition, cancer cells tend to repress the expression of tumor-specific antigen and MHC complex molecules. Dendritic cells based immunotherapies did not allow significant clinical responses in relapsed disease even if immunological was detectable. Overall, the promising pre-clinical results lead to disappointing clinical data. The increased immunosuppressive cells associated to the tumor burden could be responsible of the absence of objective clinical response. In such context, it would be necessary to assess dendritic based immunotherapy in the prevention of the relapse disease (in patients without any detectable metastasis or detectable recurrent disease). Furthermore, substantial improvements of the preparation of dendritic cells are mandatory, more specifically to improve their maturation process and to optimize their capacity of tumor antigen presentation and the initiation of efficient immune response.

\section{Tumor lymphocyte infiltrate in bone sarcomas}

Bone sarcomas are also characterized by moderate lymphocyte infiltration (less than $10 \%$ of cells). In Ewing sarcoma, CD8 ${ }^{+}$TILs have been detected in tumor samples; however, they were not correlated with histological subtypes, tumor location, or programmed cell death (PD)-1 and PD-Ligand (L)-1 expression, nor with either progression-free survival or overall survival [Machado et al., 2018]. Interestingly, PD-1 was expressed in 26\% of tumor cells and may have prognostic and therapeutic implications. In chondrosarcoma, TILs were detectable and correlated with PDL-1 expression, being highly-expressed in dedifferentiated 
chondrosarcomas. PDL-1 expression was also correlated with positive HLA class I expression, but not with overall survival [Kostine et al., 2018].

In osteosarcoma, $\underline{\mathrm{CD}}^{+}$and $\mathrm{CD} 8^{+}$tumor infiltrating lymphocytes (TILs) were isolated from fresh patient samples and showed higher ex vivo cytotoxic activity than autologous circulating T cells [Théoleyre et al., 2005; Koirala et al., 2016]. In contrast to Ewing sarcoma and chondrosarcoma, the ratio between $\mathrm{CD}^{+} \mathrm{T}$ cells and regulatory $\mathrm{T}$ cells was informative in terms of overall survival, and a decreased ratio was associated with decreased survival, as shown in dogs [Biller et al., 2010]. These data have been confirmed more recently in a cohort of human osteosarcoma patients and revealed that quantification of the $\mathrm{CD} 8^{+} / \mathrm{FOXP} 3^{+}$-ratio in biopsies prior to chemotherapy makes it possible to identify patients with better survival [Fritzsching et al., 2015]. However, an increase in $\mathrm{CD}^{+} 4^{+}$macrophage infiltrates is associated with Cytotoxic T-Lymphocyte Associated Protein 4 positive $\left(\underline{\mathrm{CTLA}^{-}}{ }^{+}\right) \mathrm{T}$ cells and a systemic immunosuppression status, as shown by an increased number of peripheral CD14 ${ }^{+}$HLA-DR ${ }^{\text {low/neg }}$ immunosuppressive monocytes [Hingorani et al., 2015]. Thus, despite the presence of macrophage and T-lymphocyte infiltrates, local immunosuppressive signals result in a tolerant environment and disease progression. A phase 2 (ClinicalTrial.gov, nNCT03449108, sponsor: M.D. Anderson Cancer Center, USA) is currently recruiting bone sarcoma patients to evaluate the efficacy of autologous tumor infiltrating lymphocytes LN145 (LN-145). The estimated study completion date is end of 2021 (Table 2).

Recently, D'Angelo et al. (2018) reported the therapeutic benefit of autologous $\mathrm{T}$ cells expressing NY-ESO-1 $1^{\text {c259 }}$ in synovial sarcoma. Similar approach is currently under investigation in bone sarcomas (ClinicalTrial.gov nNCT03462316, Phase 1 "NY-ESO-1 specific T cell receptor (TCR) T cell in sarcoma”, sponsor: Sun Yat-sen University, China) 
(Table 2). Patients HLA-A*0201+ and exhibiting an initial tumor biopsy with more than $25 \%$ of NY-ESO-1 positive tumor cells could be enrolled. $\gamma \delta$ T-lymphocytes represent $1-5 \%$ of total blood T-lymphocytes in peripheral blood. $\gamma 9 \delta 2$ T-lymphocyte heterodimers of V $\delta 2$ and $\mathrm{V} \gamma 9$ chains constitute around $50-95 \%$ of all blood $\gamma \delta \mathrm{T}$ cell populations [Silva-Santos et al., 2015]. V $\gamma 9 \mathrm{~V} \delta 2$ T-lymphocytes are specifically dedicated to the recognition of non-peptidic antigens including pyrophosphomonoesters and alkylamines from microbial metabolites or organic compounds such as nitrogen-containing bisphosphonates. From these observations, several preclinical studies have provided evidence of the therapeutic benefits of using $\gamma \delta \mathrm{T}$ lymphocyte-based adoptive therapies with promising results [Murano et al., 2007; Li et al., 2012; Liu et al., 2015; Wang, et al., 2018]. $\gamma \delta$ T-lymphocyte activation contributes to tumor cell recognition through the engagement of TCR and/or NK receptors, including NKGD2 [Silva-Santos et al., 2015]. The low expression of NKGD2 may restrain the $\gamma \delta$ T-lymphocyte response against tumor cells. To improve the tumor response of $\gamma \delta \mathrm{T}$ cells, Wang Z. et al. (2018) combined $\mathrm{T}$ cell therapies with decitabine, which may enhance NKG2D expression by osteosarcoma cells and then subsequently stimulate the cytolysis depending on the NKG2D NKG2D ligand axis. Pre-treatment with nitrogen bisphosphonates has also been proposed to activate $\gamma \delta$ T-lymphocytes thanks to isopentenyl pyrophosphate release, which is produced after the internalization of nitrogen bisphosphonates by peripheral blood mononuclear cells [Wang S. et al., 2018; Li et al., 2012]. Unfortunately, recent knowledge has revealed the deleterious activities of $\gamma \delta \mathrm{T}$ cells, which may promote tumor progression by acting as $\mathrm{T}$ regulator cells and inducing local immunosuppression, by interfering with dendritic cells and inhibiting the PD1-PDL1 functional pathway [Fleming et al., 2017]. In this context, other adoptive therapies have been proposed to modulate the immune response in bone sarcoma. 
Natural killer (NK) cells are a subset of lymphocytes that belong to the innate immune system and play a crucial role in the immune response against tumor cells and virus-infected cells, independently of any prior sensitization to antigens for the target recognition. NK adoptive therapies have already been assessed in murine models of bone sarcomas [Fernandez et al., 2017; Guma et al., 2014]. By using a model of metastatic osteosarcoma, a combination of NK cell therapy and inhalation of $\underline{\mathrm{IL}-2}$ showed promising results and improved the survival of mice suffering from lung metastases [Guma et al., 2014]. Fernandez et al. (2015) demonstrated the beneficial effects of expanded activated NK cells in vitro, and in an in vivo murine osteosarcoma model that was associated with marked NKGD2-NKGD2L cytolysis of all cancer cell subtypes, including tumor-initiating cells (Figure 1C). NK cell-based clinical trials are currently in progress. The NKEXPSARC study "Pilot study of expanded, activated haploidentical natural killer cell infusions for sarcomas" (ClinicalTrial.gov $\mathrm{N}^{\circ}$ NCT02409576; sponsor: National University Hospital, Singapore) plans to analyze NK cell infusion in Ewing sarcomas (Table 2). The patients enrolled will receive lymphodepleting chemotherapy with cyclophosphamide ( 1 day) followed by fludarabine (5 days), and each patient will receive IL-2 on alternate days starting 1 day before infusion of the NK cells for a total of 6 doses. NCT02890758 (sponsor: Case Comprehensive Cancer Center, USA) is a phase 1 trial analyzing universal donor NK cell therapy in combination with a new compound (ALT803) that improves the survival of NK cells. Ewing patients will be enrolled. The STIR phase 2 study (ClincialTrial.gov nNCT02100891; sponsor: Medical College of Wisconsin, USA) will study haploidentical transplant and donor NK cells for solid tumors. Twenty patients will receive a reduced-intensity conditioning regimen (6 days) consisting of fludarabine $\left(150 \mathrm{mg} / \mathrm{m}^{2}\right)$, cyclophosphamide $(29 \mathrm{mg} / \mathrm{kg})$, and 3 Gy total body irradiation, followed by HLA-haploidentical marrow from a family member on Day 0 . On days 3 and 4, cyclophosphamide $(50 \mathrm{mg} / \mathrm{kg})$ will be infused for selective in vivo $\mathrm{T}$ cell depletion. 
Additional post-grafting immune suppression will associate mycophenolate mofetil with either tacrolimus or sirolimus. NK cells will be selected from non-mobilized peripheral blood mononuclear cells on day 6 and infused into patients on day 7. The last one (Title: "Haploidentical stem cell transplantation and NK cell therapy in patients with high-risk solid tumors"; ClinicalTrial.gov nNCT01807468) is sponsored by the Samsung Medical Center (Republic of Korea) and will recruit 12 patients, including osteosarcoma and Ewing sarcoma patients, who will receive expanded NK cell infusions and low-dose IL-2 to enhance NK cell alloreactivity.

\section{Genetically-modified T lymphocyte therapies}

To bypass human leukocyte antigen restrictions, the concept of chimeric antigen receptor (CAR) engineered T-lymphocytes (CAR T-cells) has been developed. CAR T-cells consist of a fusion of specific antibody-derived single-chain variable fragments with the signaling domain of a $\mathrm{T}$ cell receptor. The fusion leads to the expression of a chimeric receptor capable of recognizing antigens and inducing conventional activation signals from TCR [DeRenzo and Gottschalk, et al., 2016]. The main advantage of CAR T-cells compared to $\alpha \beta$ TCR Tlymphocytes is that CAR T-cells can induce tumor death in a non-MHC restricted manner and may overcome the low levels of tumor antigen expression by cancer cells [Ahmed et al., 2009] (Figure 1C). Diverse CAR T-cells have been developed based on this concept: CAR T-

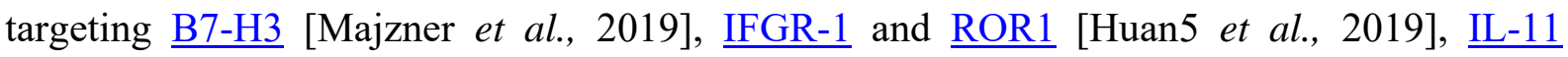
[Huang et al., 2012], Folate receptor [Lu et al., 2019], NKG2D/4-1BB/CD3z domains [Fernandez et al., 2017], and CD166/4-1BB [Wang et al., 2019]. A phase 1/2 clinical trial was conducted by Ahmed et al. (2015) in which patients with recurrent/refractory osteosarcoma $(\mathrm{n}=16)$ and Ewing sarcoma $(\mathrm{n}=1)$ expressing $\underline{\text { HER2 }}$ received escalating doses of CAR T-cells targeting HER2. Interestingly, HER2-CAR T-cells were detectable in circulating 
blood for 6 weeks after infusion and in the two patients assessed, HER2-CAR T-cells were observed at the tumor site. No sign of evident toxicity has been reported. However, although 4 patients of 17 evaluable patients had stable disease after HER2-CAR T-cell infusion, no radiologic complete responses were observed [Ahmed et al., 2015]. In this trial, the authors did not observe any HER2-CAR $\mathrm{T}$ cell expansion that may be explained by the lack of lymphodepletion before CAR T cell infusion. The ongoing clinical trial combined CAR Tcells and lymphodepletion (Table 2). Thus, four clinical trials are currently in progress. The VEGAS study "iC9-GD2-CAR-VZV-CTLs/refractory or metastatic GD2-positive sarcoma and neuroblastoma" (ClinicalTrial.gov NNCT01953900, Sponsor: Baylor College of Medicine, USA) aims to determine the largest safe dose of GD2-CAR T- cells combined with a varicella zoster vaccine and lymphodepletion by chemotherapy. Similarly, the NCT02107963 phase I trial (Sponsor: National Cancer Institute, USA) has recently been completed and assessed escalating doses of GD2 CAR T cells after cyclophosphamide-based lymphodepletion in children and young adults with $\mathrm{GD}^{+}$solid tumors, including osteosarcoma. In an open-label, non-randomized phase 1 study sponsored by the Seattle Children's Hospital (USA), CAR T-cells targeting EGFR and CD19 will be assessed, and 36 patients will be enrolled (ClinicalTrial.gov $\mathrm{n}^{\circ} \mathrm{NCT03618381,} \mathrm{"EGFR806} \mathrm{CAR} \mathrm{T-cell}$ immunotherapy for recurrent/refractory solid tumors in children and young adults"). Finally, the safety and efficacy of the $4^{\text {th }}$ generation of CAR T cell (4SCAR-Ig T-cells) targeting cells surface sarcoma antigens was initiated in 2017 by the Shenzhen Geno-Immune Medical Institute (China) (ClinicalTrial.gov n $\left.{ }^{\circ} \mathrm{NCT} 03356782\right)$. CAR T-cells have not proven yet their efficacy in bone sarcomas. However, clinical trials are mandatory to improve our knowledge about CAR T-cells functions: 1) the capacity of CAR T-cells to infiltrate metastatic foci of bone sarcomas more specifically the lung micrometastases, ii) the potential impact of the local immunosuppressive microenvironment on CAR T-cells activities, iii) the functional 
relationship between genes expressed at the metastatic sites and CAR T-cells migration and functions. Recently, Morrow et al. (2018) studied the contribution of enhancer elements to the metastatic phenotype of osteosarcoma. They identified specific regions named Metastatic Variant Enhancer Loci that drive coordinated waves of gene expression during metastatic colonization of the lung. Interestingly, the activity of these enhancers and their associated gene targets were specifically controlled and not randomly regulated. A better understanding of the relationship between epigenomic profiling of the metastatic microenvironment and infiltrating CAR T-cells would be possible by the full analysis of resection lesions and will allow to identify new potential therapeutic combinations (e.g. with immune checkpoint inhibitors).

\section{Immune checkpoint blockade in bone sarcomas}

Initial immunotherapy strategies aimed to restimulate the immune system, which was in a state of anergy. Cytokine therapies, such as inoculation/inhalation of IL-2, were proposed to activate cytotoxic T-lymphocytes with limited success in terms of survival [Mori et al., 2006]. Recent identification of multiple co-inhibitory molecules controlling the communications between cancer cells and immune actors provided a new explanation for the "immune brake" observed in oncology, opening up a new therapeutic era specifically for keeping the immune brake off. These protagonists, called immune checkpoints, include stimulatory $(\underline{\mathrm{CD} 27}, \underline{\mathrm{CD} 28}$, etc.) and inhibitory (B7-H3, CTLA-4, etc.) checkpoint molecules [Schildberg et al., 2016] (Figure 1A). Numerous recent publications have demonstrated the expression of immune checkpoints by bone sarcomas in order to escape immune surveillance. For example, osteosarcoma and chondrosarcoma express PDL-1/PDL-2 [Thanindratarn et al., 2019; McEachron et al., 2018; Yang et al., 2018; Zheng et al., 2018; Sandara et al., 2017; van Erp et al., 2017], B7-H3 [Yin et al., 2015; Wang et al., 2013], HHLA-2 [Koirala et al., 2016]. B7- 
H4 is expressed by osteosarcoma cells [Dong et al., 2015]. Ewing sarcoma expresses the B7H3 protein [Majzner et al., 2019] but not PDL-1 [Spurny et al., 2018]. Sandara et al. (2017) observed an increased number of TILs and PD-L1 expression in metastases compared to primary tumors and reinforced the therapeutic value of checkpoint inhibitors in patients with metastatic disease. In this context, the targeting PD-1/PDL-1 axis was assessed with success in preclinical models either alone [Shimizu et al., 2018; Zheng et al., 2018] or combined with irradiation [Xia et al., 2018], CTLA-4 blocking antibodies [Lussier et al., 2018], L-arginine [He et al., 2017] or myeloid-derived suppressor cells [Guan et al., 2018]. Interestingly, the PD-1 blockade increased the number of anti-tumor M1 macrophages and decreased the recruitment of pro-inflammatory M2 macrophages, resulting in regression of lung metastases in a murine model of osteosarcoma [Dhupkar et al., 2017]. As described previously for other immunotherapeutic approaches, ant-PD1 and anti-PDL1 therapeutic approaches gave disappointing results. In SARC028 phase II clinical trials (ClinicalTrials.gov, $\mathrm{n}^{\circ}$ NCT02301039), (2017) et al. assessed an anti-PD-1 antibody (Pembrolizumab) in patients suffering from soft -tissue or bone sarcoma. Forty bone sarcoma patients were enrolled and received $200 \mathrm{mg}$ i.v. pembrolizumab every 3 weeks. Only 5\% of patients had an objective response [one osteosarcoma (1/22), one chondrosarcoma (1/5) and none Ewing sarcoma (1/13)]. In the PEMBROSARC study (ClinicalTrials.gov, $\mathrm{n}^{\circ}$ NCT02406781), Le Cesne et al. (2019) assessed the combination of pembrolizumab (200 mg i.v. every 3 weeks) with metronomic cyclophosphamide (50 $\mathrm{mg}$ b.id. one week on and one week off) in patients with advanced osteosarcomas. Partial response was observed in one patient (6.66\%) of 15 enrolled, stable disease in 5 and progressive disease in 8 . Immune infiltration was detected in all patients (14 patients) for who the data were available. $\mathrm{CD}^{+}$cells were observed as well as PDL-1 expression in tumor cells. Similarly, Paoluzzi et al. (2017) have retrospectively analyzed a small cohort of patients with relapsed sarcomas including 4 bone sarcomas treated 
with an other anti-PD-1 antibody (nivolumab, $3 \mathrm{mg} / \mathrm{kg}$ i.v. every 2 weeks, median number of cycles: 8) and pazopanib (400-800 mg daily). The authors observed a partial response in one maxillary osteosarcoma. Clinical investigations of immune checkpoint inhibitors are at the early stage of knowledge in bone sarcoma and are generating considerable interest as shown by the ongoing clinical trials (Table 3 ).

\section{Perspectives and Conclusions}

Bone sarcomas are rare malignant entities characterized by rich and heterogeneous immune infiltrates which appear to be an asset for new immunotherapy programs (Figure 2). The dysregulation of macrophage recruitment in favor of anti-tumor M2 subsets, combined with regulatory $\mathrm{T}$ cell infiltrate, is responsible for an immune tolerant microenvironment which facilitates cancer cell survival, tumor growth and the metastatic process. Osteosarcoma and Ewing sarcoma are predominant in children and adolescent during bone growth. Bone remodeling is characterized by a permanent dialog between osteoblasts and osteoclasts and bone growth is marked by an increase of osteoclast number as well as osteoblastic activities. Osteoclast may play a important role in disease progression [Endo-Munoz et al., 2012]. Indeed, a lost of osteoclast may facilitate the cancer cell migration to distant site, function that they do not have at the early stage of the disease. This dual activity could be explained by the high heterogeneity of osteoclasts composed by pro-inflammatory and immunocompetent osteoclast subsets [Madel et al., 2019]. Bone cells and their functional impact in the immune system then define a unique tumor microenvironment for pediatric bone sarcomas. A better understanding and characterization of the tumour microenvironment which continuously evolve all along the disease history and the therapeutic lines with the selection is mandatory [Brown et al., 2019]. 
The SARC028 clinical trial revealed interesting clinical responses in two adult sarcomas (undifferentitated pleomorphic sarcoma and dedifferentiated liposarcoma) in contrast to pediatric sarcoma (Ewing sarcoma and osteosarcoma) for which no objective response was observed [Tawbi et al., 2017]. These results highlight a major difference between adult and pediatric cancers that may be explained by low expression of neoantigens in addition to their specific microenvironment [Chang et al., 2017; Crompton et al., 2014]. Indeed, genetic investigations have demonstrated the paucity of mutations more specifically involving targetable signal transduction pathways in pediatric sarcomas. This lack of targetable neoantigens reduces consequently the chance of success of immunotherapies. However, sarcomas are also characterized by high frequency of oncogenic fusion events responsible of the expression of fusion-derived neoantigens that represent alternative tumor-targets [Lorenz et al., 2016; Anderson et al., 2018]. Since sarcomas and most specifically pediatric sarcomas are characterized by a relatively low immunogenicity, any drug modulating the immune response, exacerbating the tumor antigen presentation would have its place in the therapeutic arsenal. PARP inhibitors are considered as immunotherapeutic sensitizers and may be one of these candidates [Césaire et al., 2018].

The use of attenuated oncolytic viruses (e.g. herpes simplex virus, Maraba virus MG1, Senaca Calley virus, etc) inoculated directly intro the tumor mass or delivered by macrophages have been proposed in oncology [Garcia-Moure et al., 2016; Muthana et al., 2013]. The main property of these viruses is their capacity to propagate preferentially in tumor environment that lacks innate defences. Oncolytic viruses then lead to a local inflammation and a secondary immune response similarly to a vaccine approach. Cripe et al. (2015) assessed an oncolytic and immunotherapeutic vaccinia virus in pediatric cancer. The formulation tested was safe and showed an objective biological activity in the Ewing sarcoma assessed, including necrotic changes in the injected tumor following the first injection. Combination 
with conventional chemotherapy or modulator of the microenvironment was also envisaged [Martinez-Velez et al., 2014 ; Denton et al., 2018].

All drugs reprogramming the immune balance in tumor tissues thus represent a therapeutic option for improving overall survival in bone sarcomas. Most bone sarcoma cells express immune checkpoint proteins, contributing to their immune escape but that also opens up new therapeutic strategies. In this field, several clinical trials assessing checkpoint inhibitors that interrupt the repressive crosstalk between cancer and immune cells are currently in progress, either as the single agent or combined with conventional chemotherapy. However, the low immunogenicity of pediatric tumors will require others approaches to unlock immunotherapeutic response. Full molecular profiling of all bone sarcomas is mandatory for looking for new tumor associated antigens and establishing a list of immune checkpoint proteins expressed by cancer cells and their environment according to histological subtypes and grading. The 100,000 genomes project in progress in the UK is one example of the ambitious ongoing project. The list of targetable biomarkers is a crucial step for future clinical development by improving patient stratification. The anecdotal immunotherapeutic responses described in most of the clinical trials is an argument in favor a better identification of patients most likely to respond and then a better selection of patients enrolled. 


\section{REFERENCES}

Ahmed, N., Brawley, V.S., Hegde, M., Robertson, C., Ghazi, A., Gerken, C., et al. (2015). Human epidermal growth factor receptor 2 (HER2)-specific chimeric antigen receptormodified $\mathrm{T}$ cells for the immunotherapy of HER2-positive sarcoma. J Clin Oncol. 33(15),1688-96. doi: 10.1200/JCO.2014.58.0225.

Ahmed, N., Salsman, V.S., Yvon, E., Louis, C.U., Perlaky, L., Wels, W.S., et al. (2009). Immunotherapy for osteosarcoma : genetic modification of $\mathrm{T}$ cells overcomes low levels of tumor antigen expression. Mol Ther. 17(10),1779-87. doi: 10.1038/mt.2009.133.

Allavena, P., Signorelli, M., Chieppa, M., Erba, E., Bianchi, G., Marchesi, F. et al. (2005). Anti-inflammatory properties of the novel antitumor agent yondelis (trabectedin): inhibition of macrophage differentiation and cytokine production. Cancer Res 65(7):2964-2971. doi: 10.1158/0008-5472.CAN-04-4037

Anderson, M.D., de Borja, R., Young, M.D., Fuligni, F., Rosic, A. Roberts, N.D. et al. (2018). Rearrangement bursts generate canonical gene fusions in bone and soft tissue tumors. Science 361(6405). doi: 10.1126/science.aam8419.

Ando, K., Mori M., Corradini, N., Redini, F., Heymann, D. (2011) Mifamurtide for the treatment of nonmetastatic osteosarcoma, Expert Opin. Pharmacother. 12 ;285-292. doi: $10.1517 / 14656566.2011 .543129$.

Borowski, A., Dirksen, U., Lixin, L., Shi, R.L., Göbel, U., Schneider, E.M. (2006). Structure and function of ETAA16: a novel cell surface antigen in Ewing's tumours. Cancer Immunol Immunother. 55(4), 363-374. doi : 10.1007/s00262-005-0017-6

Brard, C., Piperno-Neumann, S., Delaye, J., Brugières, L., Hampson, L.V. Le Teuff, G. et al. (2019). Sarcome-13/OS2016 trial protocol: a multicentre, randomised, open-label, phase II trial of mifamurtide combined with postoperative chemotherapy for patients with newly diagnosed high-risk osteosarcoma. BMJ Open 9(5),e025877. doi: 10.1136/bmjopen-2018025877.

Biller, B.J., Guth, A., Burton, J.H., Dow, S.W. (2010). Decreased ratio of CD8+ T cells to regulatory $\mathrm{T}$ cells associated with decreased survival in dogs with osteosarcoma. J Vet Intern. Med. 24 (2010) 1118-1123. doi: 10.1111/j.1939-1676.2010.0557

Bluman EM, Coulie PG, Xiaojuan S, Machan J, Lin C, Meitner PA, et al. (2007). Lysis of human chondrosarcoma cells by cytolytic $\mathrm{T}$ lymphocytes recognizing a MAGE-A3 antigen presented by HLA-A1 molecules. J Orthop Res. 25, 678-684. doi : 10.1002/jor.20368

Brinkmann, U, Vasmatzis, G., Lee, B., Pastan, I. (1999). Novel genes in the PAGE and GAGE family of tumor antigens found by homology walking in the dbEST database. Cancer Res. 59(7), 1445-1448. PMID: 10197611

Brown, H.K., Schiavone, K., Gouin, F., Heymann, M.F., Heymann D. (2018). Biology of bone sarcomas and new therapeutic developments. Calcif Tissue Int. 20102(2),174-195. doi: 10.1007/s00223-017-0372-2. 
Brown, H.K., Tellez-Gabriel, M., Cartron, P.F., Vallette, F.M., Heymann, M.F., Heymann, D. (2019). Characterization of circulating tumor cells as a reflection of the tumor heterogeneity: myth or reality? Drug Discov Today 24(3),763-772. doi: 10.1016/j.drudis.2018.11.017

Buddingh, E.P., Kuijjer, M.L., Duim, R.A., Bürger, H., Agelopoulos, K., Myklebost, O., et al. (2011). Tumor-infiltrating macrophages are associated with metastasis suppression in highgrade osteosarcoma: a rationale for treatment with macrophage activating agents. Clin Cancer Res. 17,2110-2119. doi: 10.1158/1078-0432.CCR-10-2047.

Burnet, F.M. (1970). The concept of immunological surveillance. Prog Exp Tumor Res. 13,127. PMID: 4921480

Césaire, M. Thariat, J., Candéias, S.M., Stefan, D., Saintigny, Y., Chevalier, F. (2018). Combining PARP inhibition, radiation, and immunotherapy: A possible strategy to improve the treatment of cancer? Int J Mol Sci. 19(12). doi: 10.3390/ijms19123793.

Chang, T.C., Carter, R.A., Li, Y., Li, Y., Wang, H., Edmonson, M.N., et al. (2017). The neoepitope landscape in pediatric cancers. Genome Med. 9(1),78. doi: 10.1186/s13073-0170468-3

Chou, A.J., Kleinerman, E.S., Krailo, M.D., et al. (2009). Addition of muramyl tripeptide to chemotherapy for patients with newly diagnosed metastatic osteosarcoma: a report from the Children's Oncology Group. Cancer 115,5339-48. doi: 10.1002/cncr.24566

Cripe, T.P., Ngo, M.C., Geller, J.I., Louis, C.U., Currier, M.A., Racadio, J.M., et al. (2015). Phase 1 study of intratumoral Pexa-Vec (JX-594), an oncolytic and immunotherapeutic vaccinia virus, in pediatric cancer patients. Mol Ther. 23(3),602-608. doi: $10.1038 / \mathrm{mt} .2014 .243$

Crompton, B.D., Stewart, C., Taylor-Weiner, A., Alexe, G., Kurek, K., et al. (2014). The genomic landscape of pediatric Ewing sarcoma. Cancer Discov. 4(11),1326-1341. doi: 10.1158/2159-8290.CD-13-1037

D’Angelo, S.P., Melchiori, L., Merchant, M.S., Bernstein, D., Glod, J., Kaplan, R. et al. (2018). Antitumor activity associated with prolonged persistence of adoptively transferred NY-ESO-1 ${ }^{\text {c259 }}$ T cells in synovial sarcoma. Cancer Discov. 8(8), 944-957. doi: 10.1158/21598290.CD-17-1417

D’Arcy, P., Maruwge, W., Wolahan, B., Ma, L., Brodin, B. (2014). Oncogenic functions of the cancer-testis antigen SSX on the proliferation, survival, and signaling pathways of cancer cells. PLoS One. 9(4),e95136. doi: 10.1371/journal.pone.0095136. eCollection 2014.

Denton, N.L., Chen, C.Y., Hutzen, B., Currier, M.A., Scott, T., Nartker, B., et al. (2018). Myelolytic treatments enhance oncolytic herpes virotherapy in models of Ewing sarcoma by modulating the immune microenvironment. Mol Ther Oncolytics 11,62-74. doi: 10.1016/j.omto.2018.10.001.

DeRenzo, C., Gottschalk, S. (2016). Genetically modified T-cell therapy for the treatment of 
osteosarcoma: an update. J Clin Cell Immunol. 7(2). doi: 10.4172/2155-9899.1000417

Dong, Q., Ma, X. B7-H4 expression is associated with tumor progression and prognosis in patients with osteosarcoma. Biomed Res Int. 2015,156432. doi: 10.1155/2015/156432.

Dhupkar, P., Gordon, N., Stewart, J., Kleinerman, E.S. (2018). Anti-PD-1 therapy redirects macrophages from an M2 to an M1 phenotype inducing regression of OS lung metastases. Cancer Med. 7(6),2654-2664. doi: 10.1002/cam4.1518.

Dumars, C., Ngyuen, J.M., Gaultier, A., Lanel, R., Corradini, N., Gouin F., et al. (2016) Dysregulation of macrophage polarization is associated with the metastatic process in osteosarcoma.Oncotarget 7(48),78343-78354. doi: 10.18632/oncotarget.13055.

Dunn, G.P., Old, L.J., Schreiber, R.D. (2004) The three Es of cancer immunoediting. Annu Rev Immunol. 22,329-60. doi: 10.1146/annurev.immunol.22.012703.104803

Endo-Munoz, L., Evdokiou, A., Saunders, N.A. (2012). The role of osteoclasts and tumourassociated macrophages in osteosarcoma metastasis. Biochim Biophys Acta 1826(2),434-42. doi: 10.1016/j.bbcan.2012.07.003.

Fang, X., Jiang, C., Xia, Q. (2015). Effectiveness evaluation of dendritic cell immunotherapy for osteosarcoma on survival rate and in vitro immune response. Genet Mol Res. 14(4),1176370. doi: 10.4238/2015.October.2.10.

Fernández, L., Metais, J.Y., Escudero, A., Vela, M., Valentín, J., Vallcorba, I., et al. (2017). Memory T cells expressing an NKG2D-CAR efficiently target osteosarcoma cells. Clin Cancer Res. 23(19),5824-5835. doi: 10.1158/1078-0432.CCR-17-0075.

Fernández, L., Valentín, J., Zalacain, M., Leung, W., Patiño-García, A., Pérez-Martínez, A. (2015). Activated and expanded natural killer cells target osteosarcoma tumor initiating cells in an NKG2D-NKG2DL dependent manner. Cancer Lett. 368(1),54-63. doi: 10.1016/j.canlet.2015.07.042.

Fiore, F., Castella, B., Nuschak, B., Bertieri, R., Mariani, S., Bruno, B., et al. (2007). Enhanced ability of dendritic cells to stimulate innate and adaptive immunity on short-term incubation with zoledronic acid. Blood 110(3),921-927. doi : 10.1182/blood-2006-09-044321

Fleming, C., Morissey, S., Cai, Y., Yan. J (2017). $\gamma \delta$ T Cells: Unexpected Regulators of Cancer Development and Progression. Trends Cancer. 3(8),561-570. doi: 10.1016/j.trecan.2017.06.003.

Foell, J.L., Hesse, M., Volkmer, I., Schmiedel, B.J., Neumann, I., Staege, M.S. (2008). Membrane-associated phospholipase A1 beta (LIPI) Is an Ewing tumour-associated cancer/testis antigen. Pediatr Blood Cancer 51(2),228-234. doi: 10.1002/pbc.21602.

Foucher, E.D., Blanchard, S., Preisser, L., Garo, E., Ifrah, N., Guardiola, P., et al. (2013). IL34 induces the differentiation of human monocytes into immunosuppressive macrophages. 
antagonistic effects of GM-CSF and IFN $\gamma$. PLoS One 8(2), e56045. doi: 10.1371/journal.pone.0056045.

Fritzsching, B., Fellenberg, J., Moskovszky, L., Sápi, Z., Krenacs, T., Machado, I., et al. (2015). $\mathrm{CD}^{+} / \mathrm{FOXP}^{+}$ratio in osteosarcoma microenvironment separates survivors from nonsurvivors: a multicentre validated retrospective study. Oncoimmunology 4; e990800. DOI: $10.4161 / 2162402 X .2014 .990800$

Garcia-Moure, M., Martinez-Vélez, N., Patiño-García, A., Alonso, M.M. (2016). Oncolytic adenoviruses as a therapeutic approach for osteosarcoma: A new hope. J Bone Oncol 9,41-47. doi: 10.1016/j.jbo.2016.12.001

Germano, G., Frapolli, R., Simone, M., Tavecchio, M., Erba, E., Psce, S. et al. (2010). Antitumor and anti-inflammatory effects of trabectedin on human myxoid liposarcoma cells. Cancer Res 70(6),2235-44. doi: 10.1158/0008-5472.CAN-09-2335.

Germano, G., Frapolli, R., Belgiovine, C., Anselmo, A., Pesce, S., Liguori, M., et al. (2013) Role of macrophage targeting in the antitumor activity of trabectedin. Cancer Cell 23(2),24962. doi: 10.1016/j.ccr.2013.01.008.

Grignani, G., D'Ambrosio, L., Pignochino. Y. (2018). Trabectedin and olaparib in patients with advanced and non-resectable bone and soft-tissue sarcomas (TOMAS): an open-label, phase 1b study from the Italian Sarcoma Group. Lancet Oncol. 19(10),1360-1371. doi: 10.1016/S1470-2045(18)30438-8.

Guan, Y., Zhang, R., Peng, Z., Dong, D., Wei, G., Wang, Y. (2017). Inhibition of IL-18mediated myeloid derived suppressor cell accumulation enhances anti-PD1 efficacy against osteosarcoma cancer. J Bone Oncol. 9,59-64. doi: 10.1016/j.jbo.2017.10.002.

Guma, S.R., Lee, D.A., Ling, Y., Gordon, N., Kleinerman, E.S. (2014). Aerosol interleukin-2 induces natural killer cell proliferation in the lung and combination therapy improves the survival of mice with osteosarcoma lung metastasis. Pediatr Blood Cancer. 61(8),1362-8. doi: $10.1002 / \mathrm{pbc} .25019$.

Han, Q., Shi, H., Liu, F. (2016). CD163(+) M2-type tumor-associated macrophage support the suppression of tumor-infiltrating $\mathrm{T}$ cells in osteosarcoma. Int Immunopharmacol. 34,101106. doi: 10.1016/j.intimp.2016.01.023.

He, X., Lin, H., Yuan, L., Li, B. (2017). Combination therapy with L-arginine and $\alpha$-PD-L1 antibody boosts immune response against osteosarcoma in immunocompetent mice. Cancer Biol Ther. 18(2),94-100. doi: 10.1080/15384047.2016.1276136.

He, Y.T., Zhang, Q.M., Kou, Q.C., Tang, B. (2016). In vitro generation of cytotoxic T lymphocyte response using dendritic cell immunotherapy in osteosarcoma. Oncol Lett. 12(2),1101-1106. DOI:10.3892/ol.2016.4714 
Heiner, J.P., Miraldi, F., Kallick, S., Makley, J., Neely, J., Smith-Mensah, W.H., et al. (1987). Localization of GD2-specific monoclonal antibody 3F8 in human osteosarcoma. Cancer Res. 47(20), 5377-5381. PMID: 3115567

Hesketh, A.J., Maloney, C., Behr, C.A., Edleman, M.C., Glick, R.D., Al-Abed, Y. et al. (2015). The macrophage inhibitor CNI-1493 blocks metastasis in a mouse model of Ewing sarcoma through inhibition of extravasation. PLoS One. 10(12),e0145197. doi: 10.1371/journal.pone.0145197.

Heymann, M.F., Brown, H.K., Heymann, D. (2016). Drugs in early clinical development for the treatment of osteosarcoma. Expert Opin Investig Drugs. 25(11),1265-1280. DOI: $10.1080 / 13543784.2016 .1237503$

Heymann, M.F., Lézot, F., Heymann, D. (2019) The contribution of immune infiltrates and the local microenvironment in the pathogenesis of osteosarcoma. Cell Immunol. 343:103711. doi: 10.1016/j.cellimm.2017.10.011.

Higashi, H, Ito, M., Fukaya, N., Yamagata, S., Yamagata, T. (1990). Two-dimensional mapping by the high-performance liquid chromatography of oligosaccharides released from glycosphingolipids by endoglycoceramidase. Anal Biochem 186(2), 355-362. doi : 10.1016/0003-2697(90)90094-p

Higuchi, T., Miyake, K., Oshiro, H., Sugisawa, N., Yamamoto, N., Hayashi, K., et al. (2019). Trabectedin and irinotecan combination regresses a cisplatinum-resistant osteosarcoma in a patient-derived orthotopic xenograft nude-mouse model. Biochem Biophys Res Commun. 513(2):326-331. 10.1016/j.bbrc.2019.03.191.

Hingorani, P., Maas, M.L., Gustafson, M.P., Dickman, P., Adams, R.H., Watanabe, M., et al. (2015). Increased CTLA $-4^{+}$T cells and an increased ratio of monocytes with loss of class II $\left(\mathrm{CD} 14^{+}\right.$HLA-DR $\left.{ }^{1 / \text { neg }}\right)$ found in aggressive pediatric sarcoma patients. J Immunother. Cancer 3,35. doi: 10.1186/s40425-015-0082-0

Himoudi, N., Wallace, R., Parsley, K.L., Gilmour, K., Barrie, A.U., Howe, K., et al. (2012). Lack of T-cell responses following autologous tumour lysate pulsed dendritic cell vaccination, in patients with relapsed osteosarcoma. Clin Transl Oncol. 14(4),271-279. doi: 10.1007/s12094-012-0795-1

Huang, G., Yu, L., Cooper, L.J., Hollomon, M., Huls, H., Kleinerman, E.S. (2012). Genetically modified T cells targeting interleukin-11 receptor $\alpha$-chain kill human osteosarcoma cellsand induce the regression of established osteosarcoma lung metastases. Cancer Res. 72(1),271-81. doi: 10.1158/0008-5472.CAN-11-2778.

Huang, X., Park, H., Greene, J., Pao, J., Mulvey, E, Zhou, S.X., et al. (2015). IGF1R- and ROR1-specific CAR T cells as a potential therapy for high risk sarcomas. PLoS One. 10(7), e0133152. doi: 10.1371/journal.pone.0133152. 
Igarashi, K., Murakami, T., Kawaguchi, K., Kiyuna, T., Miyake, K., Zhang, Y., et al (2017). A patient-derived orthotopic xenograft (PDOX) mouse model of a cisplatinum-resistant osteosarcoma lung metastasis that was sensitive to temozolomide and trabectedin: implications for precision oncology. Oncotarget. 8(37),62111-62119. doi: 10.18632/oncotarget.

Inagaki, Y., Hookway, E., Williams, K.A., Hassan, AB., Oppermann, U., Tanaka, Y., et al. (2016). Dendritic and mast cell involvement in the inflammatory response to primary malignant bone tumors. Clin Sarcoma Res. 6:13. doi: 10.1186/s13569-016-0053-3. eCollection 2016.

Jacobs, J. F. M., Brasseur, F., Hulsbergen-van de Kaa, C. A., van de Rakt, M.W., Figdor, C.G., Adema, G.J., et al. (2007). Cancer-germline gene expression in pediatric solid tumors using quantitative real-time PCR. Int J Cancer 120(1),67-74. doi: 10.1002/ijc.22118.

Jeys, L.M., Grimer, R.J., Carter, S.M., Tillman, R.M., Abudu, A. Post-operative infection and increased survival in osteosarcoma patients: are they associated ? (2007). Ann Surg Oncol. 14(10 ),2887-2895. DOI: 10.1245/s10434-007-9483-8

Jones, J.D., Sinder, B.P., Paige, D., Soki, F.N., Koh, A.J., Thiele, S., et al.(2019). Trabectedin reduces skeletal prostate cancer tumor size in association with effects on M2 macrophages and efferocytosis. Neoplasia 21(2),172-184. doi: 10.1016/j.neo.2018.11.003.

Kager, L., Pötschger, Bielack, S. (2010) Review of mifamurtide in the treatment of patients with osteosarcoma. Ther Clin Risk Manag 6,279-86. doi:10.2147/tcrm.s5688

Kailayangiri, S., Altvater, B., Meltzer, J., Pscherer, S., Luecke, A., Dierkes, C., et al. (2012). The ganglioside antigen G(D2) is surface-expressed in Ewing sarcoma and allows for MHCindependent immune targeting. Br J Cancer 106(6), 1123-1133. doi: 10.1038/bjc.2012.57.

Kawano, M., Tanaka, K., Itonaga, I., Iwasaki, T., Miyazaki, M., Ikeda, S., et al. (2015). Dendritic cells combined with anti-GITR antibody produce antitumor effects in osteosarcoma. Oncol Rep. 34(4),1995-2001. doi: 10.3892/or.2015.4161.

Kelleher, F.C., O'Sullivan, H. (2017). Monocytes, Macrophages, and Osteoclasts in Osteosarcoma. J Adolesc Young Adult Oncol 6(3), 396-405. doi: 10.1089/jayao.2016.0078.

Kimura, Y., Sumiyoshi, M. (2015). Antitumor and antimetastatic actions of dihydroxycoumarins (esculetin or fraxetin) through the inhibition of M2 macrophage differentiation in tumor-associated macrophages and/or G1 arrest in tumor cells. Eur J Pharmacol. 746,115-125. doi: 10.1016/j.ejphar.2014.10.048.

Kleinerman, E.S. Gano, J.B., Johnston, D.A., Benjamin, R.S., Jaffe, N. (1995). Efficacy of liposomal muramyl tripeptide (CGP 19835A) in the treatment of relapsed osteosarcoma. Am J Clin Oncol 18(2):93-9. doi : 10.1097/00000421-199504000-00001 
Koirala, P., Roth, M.E., Gill, J., Piperdi, S., Chinai, J.M., Geller, D.S., et al. (2016). Immune infiltration and PD-L1 expression in the tumor microenvironment are prognostic in osteosarcoma. Sci Rep. 6,30093. doi: 10.1038/srep30093.

Kostine, M., Cleven, A.H., de Miranda, N.F., Italiano, A., Cleton-Jansen, A.M., Bovée, J.V. (2016). Analysis of PD-L1, T-cell infiltrate and HLA expression in chondrosarcoma indicates potential for response to immunotherapy specifically in the dedifferentiated subtype. Mod Pathol. 29(9),1028-37. doi: 10.1038/modpathol.2016.

Krishnadas, D.K., Shusterman, S., Bai, F., Diller, L., Sullivan, J.E., Cheerva, A.C., et al. (2015). A phase I trial combining decitabine/dendritic cell vaccine targeting MAGE-A1, MAGE-A3 and NY-ESO-1 for children with relapsed or therapy-refractory neuroblastoma and sarcoma. Cancer Immunol Immunother. 64(10),1251-60. doi: 10.1007/s00262-015-17313.

Kuldkepp, A., Karakai, M., Toomsoo, E., Reinsalu, O., Kurg, R. (2019). Cancer-testis antigens MAGEA proteins are incorporated into extracellular vesicles released by cells. Oncotarget 10(38),3694-3708. doi: 10.18632/oncotarget.26979.

Lai, J.P., Robbins, P.F., Raffeld, M., Aung, P.P., Tsokos, M., Rosenberg, S.A., et al. (2012). NY-ESO-1 expression in synovial sarcoma and other mesenchymal tumors: significance for NY-ESO-1-based targeted therapy and differential diagnosis. Mod Pathol. 25(6), 854-858. doi: $10.1038 /$ modpathol.2012.31.

Le Cesne, A., Marec-Berard, P., Blay, J.Y., Gaspar, N., Bertucci, F., Penel, N., et al. (2019) Programmed cell death 1 (PD-1) targeting in patients with advanced osteosarcomas: results from the PEMBROSARC study. Eur J Cancer 119, 151-157. doi: 10.1016/j.ejca.2019.07.018.

Li, Y., Wang, D., Fang, X. (2019). In vitro generation of anti-osteosarcoma cytotoxic activity using dendritic cells loaded with heat shock protein 70-peptide complexes. Fetal Pediatr Pathol. 1-12. doi: 10.1080/15513815.2019.1600624.

Li, Z., Peng, H., Xu, Q., Ye, Z. (2012). Sensitization of human osteosarcoma cells to Vg9d2 T cell mediated cytotoxicity by zoledronate. J Orthop Res. 30(5),824-30. doi: 10.1002/jor.21579

Lin, C., Mak, S., Meitner, P.A., Wolf, J.M., Bluman, E.M., Block, J.A., et al. (2002). Cancer/testis antigen CSAGE is concurrently expressed with MAGE in chondrosarcoma. Gene 285(1-2), 269-78. doi: 10.1016/s0378-1119(02)00395-5

Lin, W., Xu, D., Austin, C.D., Caplazi, P., Senger, K., Sun, Y., et al. (2019). Function of CSF1 and IL34 in Macrophage Homeostasis, Inflammation, and Cancer. Front Immunol. 2019 Sep 4;10:2019. doi: 10.3389/fimmu.2019.02019.

Lipinski, M., Braham, K., Philip, I., Wiels, J., Philip, T., Goridis, C., et al. (1987). Neuroectoderm-associated antigens on Ewing's sarcoma cell lines. Cancer Res. 47(1), 183187. PMID: 3024814 
Liu, M., Sun, L.L., Li, Y.J., Li, H.Y., Zhang, J., Li, B.H., et al. (2015). Trastuzumab enhanced the cytotoxicity of $\mathrm{V} \gamma 9 \mathrm{~V} \delta 2 \mathrm{~T}$ cells against zoledronate-sensitized osteosarcoma cells. Int Immunopharmacol. 28(1),160-7. doi: 10.1016/j.intimp.2015.06.002.

Lorenz, S., Barøy, T., Sun, J., Nome, T., Vodák, D., Bryne, J.C., Håkelien, A.M., et al. (2016). Unscrambling the genomic chaos of osteosarcoma reveals extensive transcript fusion, recurrent rearrangements and frequent novel TP53 aberrations. Oncotarget 7(5), 5273-88. doi: 10.18632/oncotarget. 6567

Lu, Y.J., Chu, H., Wheeler, L.W., Nelson, M., Westrick, E., Matthaei, J.F., et al. (2019). Preclinical evaluation of bispecific adaptor molecule controlled folate receptor CAR-T cell therapy with special focus on pediatric malignancies. Front Oncol. 9:151. doi: 10.3389/fonc. 2019.00151 .

Lussier, D.M., Johnson, J.L., Hingorani, P., Blattman, J.N. (2015). Combination immunotherapy with $\alpha$-CTLA- 4 and $\alpha$-PD-L1 antibody blockade prevents immune escape and leads to complete control of metastatic osteosarcoma. J Immunother Cancer. 3,21. doi: 10.1186/s40425-015-0067-z

Machado, I., Lopez-Guerrero, J.A., Scotlandi, K., Picci, P., Llombart-Bosch, A. (2018). Immunohistochemical analysis and prognostic significance of PD-L1, PD-1, and CD8+ tumor-infiltrating lymphocytes in Ewing's sarcoma family of tumors (ESFT). Virchows Arch. 472(5),815-824. doi: 10.1007/s00428-018-2316-2.

Madel, M.B., Ibáñez, L., Wakkach, A., de Vries, T.J., Teti, A., Apparailly, F., et al. (2019) Immune function and diversity of osteoclasts in normal and pathological conditions. Front Immunol. 2019 Jun 19;10:1408. doi: 10.3389/fimmu.2019.01408

Marina-Garcia, N., Franchi, L., Kim, Y.G., Miller, D., McDonald, C., Boons, G.J., Nunez, G. (2008). Pannexin-1-mediated intracellular delivery of muramyl dipeptide induces caspase-1 activation via cryopyrin/NLRP3 independently of Nod2. J Immunol 180(6),4050-4057. doi: 10.4049/jimmunol.180.6.4050

Majzner, R.G., Simon, J.S., Grosso, J.F., et al. (2017). Assessment of programmed deathligand 1 expression and tumor-associated immune cells in pediatric cancer tissues. Cancer 123(19),3807-3815. doi: 10.1002/cncr.30724. Epub 2017 Jun 13.

Majzner, R.G., Theruvath, J.L., Nellan, A., Heitzeneder, S., Cui, Y., Mount, C.W., et al. (2019). CAR T cells targeting B7-H3, a pan cancer antigen, demonstrate potent preclincial activity against pediatric solid tumors and brain tumors. Clin Cancer Res. 25(8),2560-2574. doi: 10.1158/1078-0432.CCR-18-0432.

Martinez-Velez, N., Xipell, E., Jauregui, P., Zalacain, M., Marrodan, L., Zandueta, C., et al. (2014). The oncolytic adenovirus $\triangle 24-$ RGD in combination with cisplatin exerts a potent antiosteosarcoma activity. J Bone Miner Res. 29(10),2287-2296. doi: 10.1002/jbmr.2253 
McEachron, T.A., Triche, T.J., Sorenson, L., Parham, D.M., Carpten, J.D. (2018). Profiling targetable immune checkoints in osteosarcoma. Oncoimmunology. 7(12),e1475873. doi: 10.1080/2162402X.2018.1475873.

Meyers, P.A., Schwartz, C.L., Krailo, M.D., et al. (2008). Osteosarcoma: the addition of muramyl tripeptide to chemotherapy improves overall survival--a report from the Children's Oncology Group. J Clin Oncol 2008;26:633-638. doi: 10.1200/JCO.2008.14.0095.

Miwa, S., Nishida, H., Tanzawa, Y., Takeuchi, A., Hayashi, K., et al. (2017). Phase 1/2 study of immunotherapy with dendritic cells pulsed with autologous tumor lysate in patients with refractory bone and soft tissue sarcoma. Cancer. 123(9),1576-1584. doi: 10.1002/cncr.30606.

Miwa, S., Shirai, T., Yamamoto, N., Hayashi, K., Takeuchi A., Igarashi K., et al. (2019). Current and emerging targets in immunotherapy for osteosarcoma. J Oncol. 2019:7035045. doi: $10.1155 / 2019 / 7035045$.

Mori, K., Ando, K., Heymann, D. (2008). Liposomal muramyl tripeptide phosphatidyl ethanolamine: a safe and effective agent against osteosarcoma pulmonary metastases, Expert Rev Anticancer Ther. 8,151-159. doi: 10.1586/14737140.8.2.151.

Mori, K., Rédini, F., Gouin, F., Cherrier, B., Heymann, D. (2006). Osteosarcoma : current status of immunotherapy and future trends. Oncol Rep. 15(3),693-700. doi.org/10.3892/or.15.3.693

Morrow, J.J., Bayles, I., Funnell, A.P.W., Miller, T.E., Saiakhova, A., Lizardo, M.M., et al. (2018). Positively selected enhancer elements endow osteosarcoma cells with metastatic competence. Nat Med. 24(2), 176-185. doi: 10.1038/nm.4475.

Muraro, M; Mereuta, O.M., Carraro, F., Madon, E., Fagioli, F. (2007). Osteosarcoma cell line growth inhibition by zoledronate-stimulated effector cells. Cell Immunol. 249(2),63-72. doi: 10.1016/j.cellimm.2007.11.005.

Muthana, M., Rodrigues, S., Chen, Y.Y., Welford, A., Hughes, R., Tazzyman, S., et al. (2013). Macrophage delivery of an oncolytic virus abolishes tumor regrowth and metastasis after chemotherapy or irradiation. Cancer Res. 73(2),490-5. doi: 10.1158/0008-5472.CAN-123056

Nardin, A., Lefbvre, M.L., Labroquère, K., Faure, O., Abastado, J.P. (2006). Liposomal muramyl tripeptide phosphatidylethanolamine: Targeting and activating macrophages for adjuvant treatment of osteosarcoma. Curr Cancer Drug Targets 6(2),123-33. DOI : $10.2174 / 156800906776056473$

Noy, R., Pollard, J.W. (2014). Tumor-associated macrophages: from mechanisms to therapy, Immunity 41, 49-61. doi: 10.1016/j.immuni.2014.06.010.

Pahl, J.H., Kwappenberg, K.M., Varypataki, E.M., Santos, S.J., Kuijjer, M.L., Mohamed, S., et al. (2014). Macrophages inhibit human osteosarcoma cell growth after activation with the bacterial cell wall derivative liposomal muramyl tripeptide in combination with interferon- $\square$. J Exp Clin Cancer Res. 33,27. doi: 10.1186/1756-9966-33-27. 
Palmerini, E., Agostinelli, C., Picci, P., Pileri, S., Marafioti, T., Lollini, P.L., et al. (2017). Tumoral immune-infiltrate (IF), PD-L1 expression and role of CD8/TIA-1 lymphocytes in localized osteosarcoma patients treated within protocol ISG-OS1. Oncotarget 8,111836111846. doi: 10.18632/oncotarget.22912.

Pignochino, Y., Capozzi, F., D’Ambrosio, L., Dell'Aglio, C., Basirico, M ., Canta, M. et al. (2017). PARP1 expression drives the synergistic antitumor activity of trabectedin and PARP1 inhibitors in sarcoma preclinical models. Mol Cancer 16(1),86. doi: 10.1186/s12943-0170652-5.

Pollack, S.M,. Li, Y., Blaisdell, M.J., Farrar, E.A., Chou, J., Hoch, B.L., et al. (2012). NYESO-1/LAGE-1s and PRAME are targets for antigen specific T cells in chondrosarcoma following treatment with 5-Aza-2-deoxycitabine. PLoS One 7(2), e32165. doi: 10.1371/journal.pone.0032165.

Polychronidou, G., Karavasilis, V., Pollack, S.M., Huang, P.H., Lee, A., Jones, R.L. (2017). Novel therapeutic approaches in chondrosarcoma. Future Oncol. 13(7),637-648. doi: 10.2217/fon-2016-0226.

Ratti, C., Botti, L., Cancila, V., Galvan, S., Torselli, I., Garofalo, C., et al. (2017) Trabectedin overrides osteosarcoma differentiative block and reprograms the tumor immune environment enabling effective combination with immune checkpoint inhibitors. Clin Cancer Res. 23(17),5149-5161. doi: 10.1158/1078-0432.

Scott, M.C., Temiz, N.A., Sarver, A.E., LaRue, R.S., Rathe, S.K., Varshney, J., et al. (2018). Comparative transcriptome analysis quantifies immune cell transcript levels, metastatic progression, and survival in osteosarcoma. Cancer Res. 78(2),326-337. doi: 10.1158/00085472.CAN-17-0576.

Schildberg, F.A., Klein, S.R., Freeman, G.J., Sharpe, A.H. (2016). Coinhibitory pathways in the B7-CD28 ligand-receptor family. Immunity. 44(5),955-72. doi: 10.1016/j.immuni.2016.05.002.

Ségaliny, A.I., Mohamadi, A., Dizier, B., Lokajczyk, A., Brion, R., Lanel, R., et al. Interleukin-34 promotes tumor progression and metastatic process in osteosarcoma trhough induction of angiogenesis and macrophage recruitment. Int $\mathrm{J}$ Cancer 137,73-85. doi: 10.1002/ijc.29376.

Shimizu, T., Fuchimoto, Y., Okita, H., Fukuda, K., Kitagawa, Y., Ueno, S., et al. (2018). A curative treatment strategy using tumor debulking surgery combined with immune checkpoint inhibitors for advanced pediatric solid tumors: An in vivo study using a murine model of osteosarcoma. J Pediatr Surg. 53(12),2460-2464. doi: 10.1016/j.jpedsurg.2018.08.023

Silva-Santos, B., Serre K., Norell, H. (2015). $\gamma \delta$ T cells in cancer. Nat Rev Immunol. 15(11),683-91. doi: 10.1038/nri3904. 
Simard, F.A., Richert, I., Vandermoeten. A., Decouvelaere, A.V., Michot J.P., Caux, C., et al. (2016) Description of the immune microenvironment of chondrosarcoma and contribution to progression. Oncoimmunology. 6(2),e1265716. doi: 10.1080/2162402X.2016.1265716.

Spurny, C., Kailayangiri, S., Jamitzky, S., Altvater, B., Wardelmann, E., Dirksen, U., et al. (2018). Programmed cell death ligand 1 (PD-L1) expression is not a predominant feature in Ewing sarcomas. Pediatr Blood Cancer. 65(1). doi: 10.1002/pbc.26719

Sundara, Y.T., Kostine, M., Cleven, A.H., Bovée, J.V., Schilham, M.W., Cleton-Jansen, A.M. (2017). Increased PD-L1 and T-cell infiltration in the presence of HLA class I expression in metastatic high-grade osteosarcoma: a rationale for T-cell-based immunotherapy. Cancer Immunol Immunother. 66(1):119-128. doi: 10.1007/s00262-016-1925-3.

Tan, P., Zou, C., Yong, B., Han, J., Zhang, L., Su, Q., et al. (2012). Expression and prognostic relevance of PRAME in primary osteosarcoma. Biochem Biophys Res Commun. 419(4),801-808. doi: 10.1016/j.bbrc.2012.02.110.

Tellez-Gabriel, M., Heymann, M.F., Heymann, D. (2019). Circulating tumor cells as a tool for assessing tumor heterogeneity. Theranostics 9(16),4580-4594. doi: 10.7150/thno.34337.

Thanindratarn, P., Dean, D.C., Nelson, S.D., Hornicek, F.J., Duan, Z. (2019). Advances in immune checkpoint inhibitors for bone sarcoma therapy. J Bone Oncol. 15,100221. doi: 10.1016/j.jbo.2019.100221.

Théoleyre, S., Mori, K., Cherrier, B., Passuti, N., Gouin, F., Rédini F., et al. (2005). Phenotypic and functional analysis of lymphocytes infiltrating osteolytic tumors: use as a possible therapeutic approach of osteosarcoma. BMC Cancer. 5:123. DOI: 10.1186/14712407-5-123

Tsuda, N., Murayama, K., Ishida, H., Matsunaga, K., Komiya, S., Itoh, K., et al. (2001). Expression of a newly defined tumor-rejection antigen SART3 in musculoskeletal tumors and induction of HLA class I-restricted cytotoxic T lymphocytes by SART3-derived peptides. J Orthop Res. 19(3),346-351. doi : 10.1016/S0736-0266(00)90031-7

Twabi, H.A., Burgess, M., Bolejack, V., Van Tine, B.A., Schuetze, S.M., Hu, J., D’Angelo, S., et al. (2017). Pembrolizumab in advanced soft-tissue sarcoma and bone sarcoma (SARC028): a multicentre, two-cohort, single-arm, open-label, phase 2 trial. Lancet Oncol. 18(11):1493-1501. doi: 10.1016/S1470-2045(17)30624-1.

van Erp, A.E.M., Versleijen-Jonkers, Y.M.H., Hillebrandt-Roeffen, M.H.S,. van Houdt, L., Gorris, M.A.J., van Dam, L.S., et al. (2017). Expression and clinical association of programmed cell death-1, programmed death-ligand- 1 and $\mathrm{CD}^{+}$lymphocytes in primary sarcomas is subtype dependent. Oncotarget. 2017 Jul 7;8(41):71371-71384. doi: 10.18632/oncotarget.19071.

Wang, S., Li, H., Ye, C., Lin, P., Li, B., Zhang, W., et al. (2018). Valproic acid combined with zoledronate enhance $\gamma \delta \mathrm{T}$ cell-mediated cytotoxicity against osteosarcoma cells via the 
accumulation of mevalonate pathway intermediates. Front Immunol. 9 ,377.

Wang, L., Zhang, Q., Chen, W., Shan, B., Ding, Y., Zhang, G., et al. (2013). B7-H3 is overexpressed in patients suffering osteosarcoma and associated with tumor aggressiveness and metastasis. PLoS One. 8(8,e70689. doi: 10.1371/journal.pone.0070689.

Wang, Y., Yu, W., Zhu, J., Wang, J., Xia, K., Liang, C., et al. (2019). Anti-CD166/4-1BB chimeric antigen receptor $\mathrm{T}$ cell therapy for the treatment of osteosarcoma. J Exp Clin Cancer Res. 38(1), 168 .

Wang, Z., Wang, Z., Li, S., Li, B., Sun, L., Li, H., Lin, P., Wang, S. et al. (2018). Decitabine Enhances V $\gamma 9 \mathrm{~V} \delta 2 \mathrm{~T}$ Cell-Mediated Cytotoxic Effects on Osteosarcoma Cells via the NKG2DL-NKG2D Axis. Front Immunol. 9,1239

Whelan, J.S., Davis, L.E. (2018) Osteosarcoma, Chondrosarcoma, and Chordoma. J Clin Oncol 10;36(2):188-193. doi: 10.1200/JCO.2017.75.1743.

Withers, S.S., York, D., Choi, J.W., Woolard, K.D., Laufer-Amorim, R., Sparger, E.E., et al. (2019). Metastatic immune infiltrates correlate with those of the primary tumor in canine osteosarcoma. Vet Comp Oncol. 17(3),242-252. doi: 10.1111/vco.12459.

Xia, L., Wu, H., Qian, W. (2018). Irradiation enhanced the effects of PD-1 blockade in brain metastatic osteosarcoma. J Bone Oncol. 12,61-64. doi: 10.1016/j.jbo.2018.05.002.

Yang, X., Zhu, G., Yang, Z., Zeng, K., Liu, F., Sun, J. (2018). Expression of PD-L1/PD-L2 is associated with high proliferation index of Ki-67 but not with TP53 overexpression in chondrosarcoma. Int J Biol Markers. 1724600818774464. doi: 10.1177/1724600818774464.

Yin, S.J., Wang, W.J., Zhang, J.Y. (2015). Expression of B7-H3 in cancer tissue during osteosarcoma progression in nude mice. Genet Mol Res. 14(4),14253-61. doi: 10.4238/2015.

Zendman, A.J., Van Kraats, A.A., Weidle, U.H., Ruiter, D.J., Van Muijen, G.N. (2002). The XAGE family of cancer/testis-associated genes: alignment and expression profile in normal tissues, melanoma lesions and Ewing's sarcoma. Int J Cancer. 99(3), 361-369. doi : 10.1002/ijc. 10371

Zheng, B., Ren, T., Huang, Y., Sun, K., Wang, S., Bao, X., et al. (2018). PD-1 axis expression in musculoskeletal tumors and antitumor effect of nivolumab in osteosarcoma model of humanized mouse. Hematol Oncol. 11(1),16. doi: 10.1186/s13045-018-0560-1.

Zheng, B., Ren, T., Huang, Y., Sun, K., Wang, S., Bao, X., et al. (2018). PD-1 axis expression in musculoskeletal tumors and antitumor effect of nivolumab in osteosarcoma model of humanized mouse. J Hematol Oncol.11(1),16. doi: 10.1186/s13045-018-0560-1.

Zhou, Q., Xian, M., Xiang, S., Xiang, D., Shao, X., Wang, J., et al. (2017). All-trans retinoic acid prevents osteosarcoma metastasis by inhibiting M2 polarization of tumor-associated macrophages. Cancer Immunol Res. 5,547-559. doi: 10.1158/2326-6066.CIR-16-0259. 
Zou, C., Shen, J., Tang, Q., Yang, Z., Yin, J., Li, Z., et al. (2012). Cancer-testis antigens expressed in osteosarcoma identified by gene microarray correlate with a poor patient prognosis. Cancer 118(7),1845-1855. doi: 10.1002/cncr.26486. 
Table 1 : Tumor associated antigens expressed by bone sarcoma cells

\begin{tabular}{|c|c|c|c|c|}
\hline $\begin{array}{l}\text { Tumor } \\
\text { associated } \\
\text { antigens }\end{array}$ & Osteosarcoma & Ewing sarcoma & Chondrosarcoma & References \\
\hline CSAGE & & & + & Lin et al., 2002 ; Zhou et al., 2012 \\
\hline ETAA16 & & + & & Borowski et al., 2006 \\
\hline Gangliosides & + & + & + & $\begin{array}{l}\text { Lipinski et al., } 1987 \text {; Heiner et al., } 1987 \text {; } \\
\text { Kailyangiri et al., } 2012\end{array}$ \\
\hline LAGE & + & + & + & Pollack et al., 2012 \\
\hline LIPI-1 & & & & Foell et al., 2008 \\
\hline MAGE & + & - & + & $\begin{array}{l}\text { Jacobs et al., } 2007 \text {; Kulkepp et al., 2019; } \\
\text { Pollack et al., 2012, Bluman et al., 2007; } \\
\text { Zhou et al., } 2012\end{array}$ \\
\hline PRAME & + & & & Tan et al., 2012 \\
\hline NY-ESO-1 & + & - & + & Jacobs et al., 2007 ; Lay et al., 2012 \\
\hline SART-3 & + & + & + & Tsuda et al., 2001 \\
\hline SSX & + & & & D’Arcy et al., 2014 \\
\hline XAGE & & + & & Brinkmann et al., 1999; Zendman et al., 2002 \\
\hline
\end{tabular}


Table 2 : Cell immunotherapies in bone sarcomas : ongoing clinical trials

\begin{tabular}{|c|c|c|c|c|c|c|c|c|}
\hline Immune cells & Phase & Sponsor & Title & Treatment regimen & $\begin{array}{l}\text { Patient } \\
\text { number }\end{array}$ & $\begin{array}{c}\text { Bone } \\
\text { sarcomas } \\
\text { included }\end{array}$ & $\begin{array}{c}\text { NCT } \\
\text { reference }\end{array}$ & $\begin{array}{l}\text { Status } \\
\text { (October } \\
\text { 2019) }\end{array}$ \\
\hline $\begin{array}{l}\text { Autologous } \\
\text { tumor infiltrating } \\
\text { lymphocytes }\end{array}$ & 2 & $\begin{array}{l}\text { M.D. Anderson } \\
\text { Cancer Center } \\
\text { (USA) }\end{array}$ & $\begin{array}{l}\mathrm{LN}-145 \text { in treating } \\
\text { patients with } \\
\text { relapsed or refractory } \\
\text { ovarian cancer, } \\
\text { osteosarcoma, or } \\
\text { other bone and soft } \\
\text { tissue sarcomas }\end{array}$ & $\begin{array}{l}\text { - Cyclophosphamide } \\
\text { intravenously iv over } 2 \\
\text { hours on days }-7 \text { and }-6 \\
\text { - fludarabine phosphate iv } \\
\text { over } 30 \text { minutes daily on } \\
\text { days }-5 \text { to }-1 \\
\text {-Autologous tumor } \\
\text { infiltrating lymphocytes LN- } \\
145 \text { iv over } 45 \text { minutes and } \\
\text { aldesleukin iv over } 30 \\
\text { minutes on days } 1-4 \text { for up } \\
\text { to } 6 \text { doses. }\end{array}$ & 80 & $\begin{array}{l}{ }^{*} \mathrm{OS} \\
\mathrm{CS} \\
\mathrm{EWS}\end{array}$ & 03449108 & Recruiting \\
\hline $\begin{array}{l}\text { NY-ESO-1 TCR } \\
\text { specific T cells } \\
\text { prepared by } \\
\text { lentiviral } \\
\text { infection }\end{array}$ & 1 & $\begin{array}{l}\text { Sun Yat-sen } \\
\text { University } \\
\text { (China) }\end{array}$ & $\begin{array}{l}\text { NY-ESO-1-specific T } \\
\text { cell receptor (TCR) T } \\
\text { cell in sarcoma }\end{array}$ & $\begin{array}{l}\text { - Seven days before TCR-T } \\
\text { cell reinfusion, } \\
\text { cyclophosphamide } \\
\text { ( } 15 \mathrm{mg} / \mathrm{kg} / \mathrm{d} \times 3 \text { days })+ \text { low- } \\
\text { dose fludarabine } \\
\text { ( } 15 \mathrm{mg} / \mathrm{m} 2 / \mathrm{d} \times 3 \text { days) } \\
\text { lymphocyte clearance. } \\
\text { - Four days later, TCR-T } \\
\text { cells }\left(1 \times 10^{9}-5 \times 10^{10}\right)+\text { IL- } \\
2 \text { subcutaneous injections } \\
\text { ( } 250,000 \text { IU/twice/day) } \\
\text { within } 15-30 \text { minutes after } \\
\text { cell reinfusion. } \\
\text { - Possibility to increase } \\
\text { cyclophosphamide }(20 \\
\text { mg/kg/d } \times 3 \text { days) and } \\
\text { fludarabine ( } 25 \text { mg/m2/d } x \\
3 \text { days) for the follow-up }\end{array}$ & 20 & $\begin{array}{l}\text { OS } \\
\text { CS } \\
\text { EWS }\end{array}$ & 03676985 & Recruiting \\
\hline $\begin{array}{l}\text { Natural Killer } \\
\text { cells }\end{array}$ & 1 & $\begin{array}{l}\text { National } \\
\text { University } \\
\text { Hospital, } \\
\text { Singapore }\end{array}$ & $\begin{array}{l}\text { Pilot study of } \\
\text { expanded, activated } \\
\text { haploidentical } \\
\text { Natural Killer cell } \\
\text { infusions for }\end{array}$ & $\begin{array}{l}\text { Immunosuppressive } \\
\text { chemotherapy before } \\
\text { infusion of NK cells (Day -7 } \\
\text { cyclophosphamide at } \\
60 \mathrm{mg} / \mathrm{kg} \text { Day }-6 \text { fludarabine }\end{array}$ & 20 & EWS & 02409576 & Recruiting \\
\hline
\end{tabular}




\begin{tabular}{|c|c|c|c|c|c|c|c|c|}
\hline & & & $\begin{array}{l}\text { sarcomas } \\
\text { (NKEXPSARC) }\end{array}$ & $\begin{array}{l}\text { at } 25 \mathrm{mg} / \mathrm{m} 2 \text { daily for } 5 \\
\text { days) } \\
\text { - Radiation Each patient will } \\
\text { receive radiation within } 48 \\
\text { hr of NK cell infusion } \\
\text { - IL-2 to support NK cell } \\
\text { activation and expansion in } \\
\text { vivo Day }-1 \text { alternate day } \\
\text { for a total of } 6 \text { doses }\end{array}$ & & & & \\
\hline $\begin{array}{l}\text { Natural Killer } \\
\text { cells } \\
+ \text { ATL803 (IL-15 } \\
\text { superagonist) }\end{array}$ & 1 & $\begin{array}{l}\text { Case } \\
\text { Comprehensive } \\
\text { Cancer Center } \\
\text { (USA) }\end{array}$ & $\begin{array}{l}\text { Phase I trial of } \\
\text { universal donor NK } \\
\text { cell therapy in } \\
\text { combination with } \\
\text { ALT803 }\end{array}$ & $\begin{array}{l}\text { - Dose escalation of Natural } \\
\text { Killer (NK) Cells from two } \\
\text { infusion of } 10 \times 10^{6} \text { cells } / \mathrm{kg} \\
\text { to } 1000 \times 10^{6} \\
\text { - ATL803: } 6 \mathrm{mg} / \mathrm{kg} \text { weekly } \\
\text { for four weeks }\end{array}$ & 54 & EWS & 02890758 & Recruiting \\
\hline $\begin{array}{l}\text { Natural Killer } \\
\text { cells }\end{array}$ & 2 & $\begin{array}{l}\text { Samsung } \\
\text { Medical Center, } \\
\text { South Korea }\end{array}$ & $\begin{array}{l}\text { Haploidentical stem } \\
\text { cell transplantation } \\
\text { and NK cell therapy } \\
\text { in patients with high- } \\
\text { risk solid tumors }\end{array}$ & - & 12 & $\begin{array}{c}\text { OS } \\
\text { EWS }\end{array}$ & 01807468 & $\begin{array}{l}\text { Not yet } \\
\text { recruiting }\end{array}$ \\
\hline $\begin{array}{l}\text { iC9-GD2-CAR- } \\
\text { VZV-Cytotoxic T } \\
\text { lymphocytes }\end{array}$ & 2 & $\begin{array}{lr}\text { Baylor } & \text { College } \\
\text { of } & \text { Medicine } \\
\text { (USA) } & \end{array}$ & $\begin{array}{l}\text { iC9-GD2-CAR-VZV- } \\
\text { CTLs/refractory or } \\
\text { metastatic GD2- } \\
\text { positive sarcoma and } \\
\text { neuroblastoma } \\
\text { (VEGAS) }\end{array}$ & $\begin{array}{l}\text {-Pre-infusion } \\
\text { lymphodepletion: } \\
\text { fudarabine } \\
\text { cyclophosphamide } \\
\text { - One injection of GD2 T } \\
\text { cells followed by VZV } \\
\text { vaccine injection } 42 \text { days } \\
\text { later. From } 1 \times 10^{6} \text { cells } / \mathrm{m}^{2} \\
\text { to } 1 \times 10^{9} \text { cells } / \mathrm{m}^{2}\end{array}$ & 26 & OS & 01953900 & Recruiting \\
\hline $\begin{array}{l}\text { Autologous CD4 } \\
\text { and CD8 T cells } \\
\text { lentivirally } \\
\text { transduced to } \\
\text { express a } \\
\text { second } \\
\text { generation 4- } \\
\text { 1BBל EGFR806- } \\
\text { EGFRt }\end{array}$ & 1 & $\begin{array}{l}\text { Seattle } \\
\text { Children's } \\
\text { Hospital (USA) }\end{array}$ & $\begin{array}{l}\text { EGFR806 CAR T } \\
\text { Cell immunotherapy } \\
\text { for recurrent } \\
\text { /refractory solid } \\
\text { tumors in children } \\
\text { and young adults }\end{array}$ & - & 36 & OS, EWS, & 03618381 & Recruiting \\
\hline 4th Generation of & $1 / 2$ & Shenzhen & Safety and efficacy & - One CAR T-cell infusion, & 20 & OS & 03356782 & Recruiting \\
\hline
\end{tabular}




\begin{tabular}{|l|l|l|l|l|l|l|l|}
\hline CAR T-cells & $\begin{array}{l}\text { Geno-Immune } \\
\text { Medical Institute } \\
\text { (China) }\end{array}$ & $\begin{array}{l}\text { evaluation of 4th } \\
\text { generation safety- } \\
\text { engineered CAR T } \\
\text { cells targeting } \\
\text { sarcomas }\end{array}$ & from $1 \times 10^{6}$ to $1 \times 10^{\prime}$ cells/kg & EWS & \\
\hline
\end{tabular}

${ }^{*}$ OS : osteosarcoma ; CS : chondrosarcoma ; EWS : Ewing sarcoma 
Table 3 : Ongoing clinical trials in bone sarcomas based on inhibition of immune checkpoints

\begin{tabular}{|c|c|c|c|c|c|c|c|c|}
\hline Drug & Phase & Sponsor & Title & Drug regimen & $\begin{array}{l}\text { Patient } \\
\text { number }\end{array}$ & $\begin{array}{c}\text { Bone } \\
\text { sarcomas } \\
\text { included }\end{array}$ & $\begin{array}{c}\mathrm{NCT} \\
\text { reference }\end{array}$ & $\begin{array}{c}\text { Status } \\
\text { (October } \\
\text { 2019) }\end{array}$ \\
\hline $\begin{array}{l}\text { Avelumab (anti- } \\
\text { PDL-1) }\end{array}$ & 2 & $\begin{array}{l}\text { St. Jude } \\
\text { Children's } \\
\text { Research } \\
\text { Hospital } \\
\text { (USA) }\end{array}$ & $\begin{array}{l}\text { A phase II trial of avelumab, a } \\
\text { fully human antibody that } \\
\text { targets Cells expressing PD-L1, } \\
\text { in patients with recurrent or } \\
\text { progressive osteosarcoma }\end{array}$ & $\begin{array}{l}\text { Avelumab : } 10 \mathrm{mg} / \\
\mathrm{kg} \text { i.v. over } 60 \\
\text { minutes on days } 1 \\
\text { and } 15 \text { of each } \\
\text { cycle, with a cycle } \\
\text { lasting } 28 \text { days. } \\
\text { and } \\
\text { avelumab every } 2 \\
\text { weeks in cycles of } \\
28 \text { days for up to } \\
24 \text { months, or } 26 \\
\text { cycles. }\end{array}$ & 40 & OS & 03006848 & Recruiting \\
\hline $\begin{array}{l}\text { ZKAB001 (anti- } \\
\text { PD-L1) }\end{array}$ & $1 / 2$ & $\begin{array}{l}\text { Lee's } \\
\text { Pharmaceuti } \\
\text { cal Limited } \\
\text { (China) }\end{array}$ & $\begin{array}{l}\text { A clinical study of PD-L1 } \\
\text { antibody ZKAB001(Drug code) } \\
\text { in limited stage of high-grade } \\
\text { osteosarcoma }\end{array}$ & $\begin{array}{c}\text { ZKAB001: } 5,10 \\
\text { or } 15 \mathrm{mg} / \mathrm{kg} / \text { times } \\
\text { bi-weekly iv }\end{array}$ & $9-18$ & OS & 03676985 & Recruiting \\
\hline $\begin{array}{l}\text { SHR-1210 (anti- } \\
\text { PD-1) }\end{array}$ & 2 & $\begin{array}{l}\text { Peking } \\
\text { University } \\
\text { People's } \\
\text { Hospital } \\
\text { (China) }\end{array}$ & $\begin{array}{l}\text { Apatinib plus anti-PD1 therapy } \\
\text { for advanced osteosarcoma }\end{array}$ & $\begin{array}{l}\text { Apatinib } 500 \mathrm{mg} \text { or } \\
250 \mathrm{mg} \text { orally daily } \\
\text { and SHR-1210 } 3 \\
\mathrm{mg} / \mathrm{kg} \text { (no more } \\
\text { than } 200 \mathrm{mg} \text { ) iv } \\
\text { every } 2 \text { weeks }\end{array}$ & 43 & OS & 03359018 & $\begin{array}{l}\text { Active, } \\
\text { not } \\
\text { recruiting }\end{array}$ \\
\hline \multirow[t]{2}{*}{$\begin{array}{l}\text { Pembrolizumab } \\
\text { (anti-PD1) }\end{array}$} & 2 & $\begin{array}{l}\text { Sarcoma } \\
\text { Alliance for } \\
\text { Research } \\
\text { through } \\
\text { Collaboration } \\
\text { (USA) }\end{array}$ & $\begin{array}{l}\text { SARC028: A phase II study of } \\
\text { the anti-PD1 antibody } \\
\text { pembrolizumab (MK-3475) in } \\
\text { patients with } \\
\text { sarcomas }\end{array}$ & $\begin{array}{c}\text { Pembrolizumab } \\
\text { 200mg i.v. every } 3 \\
\text { weeks }\end{array}$ & 146 & $\begin{array}{l}\text { OS } \\
\text { CS } \\
\text { EWS }\end{array}$ & 02301039 & $\begin{array}{l}\text { Active, } \\
\text { not } \\
\text { recruiting }\end{array}$ \\
\hline & 2 & $\begin{array}{l}\text { Oslo } \\
\text { University } \\
\text { Hospital } \\
\text { (Norway) }\end{array}$ & 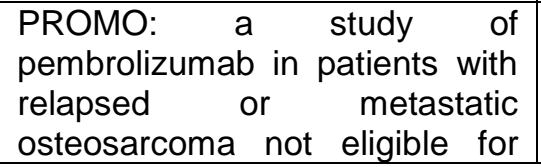 & $\begin{array}{c}\text { Pembrolizumab } \\
\text { 200mg i.v. every } 3 \\
\text { weeks for up to } 35 \\
\text { cycles } \\
\end{array}$ & 12 & OS & 03013127 & $\begin{array}{l}\text { Active, } \\
\text { not } \\
\text { recruiting }\end{array}$ \\
\hline
\end{tabular}




\begin{tabular}{|c|c|c|c|c|c|c|c|c|}
\hline & & & curative surgery & & & & & \\
\hline $\begin{array}{l}\text { Nivolumab } \\
\text { (anti-PD1) +/- } \\
\text { Ipilimumab } \\
\text { (anti-CTL4) }\end{array}$ & $1 / 2$ & $\begin{array}{l}\text { National } \\
\text { Cancer } \\
\text { Institute } \\
\text { (USA) }\end{array}$ & $\begin{array}{l}\text { Nivolumab with or without } \\
\text { ipilimumab in treating younger } \\
\text { patients with recurrent or } \\
\text { refractory solid tumors or } \\
\text { sarcomas }\end{array}$ & $\begin{array}{l}\text { Nivolumab } 240 \mathrm{mg} \\
\text { i.v. every } 2 \text { weeks } \\
\text { plus Ipilimumab } 1 \\
\mathrm{mg} / \mathrm{m}^{2} \text { i.v. every } 6 \\
\text { weeks }\end{array}$ & 484 & OS & 02304458 & Recruiting \\
\hline $\begin{array}{l}\text { Nivolumab + } \\
\text { Ipilimumab }\end{array}$ & 2 & $\begin{array}{l}\text { Assaf- } \\
\text { Harofeh } \\
\text { Medical } \\
\text { Center } \\
\text { (Israel) }\end{array}$ & $\begin{array}{l}\text { A phase II of nivolumab plus } \\
\text { ipilimumab in non-resectable } \\
\begin{array}{l}\text { sarcoma and endometrial } \\
\text { carcinoma }\end{array}\end{array}$ & $\begin{array}{l}\text { Nivolumab } 240 \mathrm{mg} \\
\text { i.v. every } 2 \text { weeks } \\
\text { plus Ipilimumab } \\
1 \mathrm{mg} / \mathrm{m}^{2} \text { i.v. every } \\
6 \text { weeks }\end{array}$ & 60 & $\begin{array}{c}\text { CS } \\
\text { EWS* }\end{array}$ & 02982486 & $\begin{array}{l}\text { Not yet } \\
\text { recruiting }\end{array}$ \\
\hline $\begin{array}{l}\text { Nivolumab + } \\
\text { ABI-009 (Nad- } \\
\text { rapamycin) }\end{array}$ & $1 / 2$ & $\begin{array}{l}\text { Sarcoma } \\
\text { Oncology } \\
\text { Research } \\
\text { Center, LLC } \\
\text { (USA) }\end{array}$ & $\begin{array}{l}\text { Nivolumab (Opdivo®) plus ABI- } \\
009 \text { (Nab-rapamycin) for } \\
\text { advanced sarcoma }\end{array}$ & $\begin{array}{c}\text { Nivolumab : } 3 \\
\text { mg/kg, IV over } 30 \\
\text { minutes q } 3 \\
\text { weeks } \\
\text { Nab-Rapamycin : } \\
\text { iv over } 30 \text { min for } \\
2 \text { of every } 3 \\
\text { weeks beginning } \\
\text { Day } 8 \text { Cycle } 2 \text {. } \\
\text { Only nivolumab } \\
\text { will be given in } \\
\text { cycle } 1 . \text { At Dose } \\
\text { level } 1,56 \text { mg/m } \\
\text { Dose level } 2,75 \\
\text { mg/m²; Dose level } \\
3,100 \mathrm{mg} / \mathrm{m}^{2} \\
\end{array}$ & 40 & $\begin{array}{c}\text { OS, EWS, } \\
\text { CS }\end{array}$ & 03190174 & Recruiting \\
\hline $\begin{array}{l}\text { Nivolumab } \\
\text { and } \\
\text { Nivolumab + } \\
\text { azacitidine }\end{array}$ & $1 / 2$ & $\begin{array}{l}\text { H. Lee Moffitt } \\
\text { Cancer } \\
\text { Center and } \\
\text { Research } \\
\text { Institute } \\
\text { (USA) }\end{array}$ & $\begin{array}{l}\text { Nivolumab or nivolumab and } \\
\text { azacitidine in patients with } \\
\text { recurrent, resectable } \\
\text { osteosarcoma }\end{array}$ & $\begin{array}{c}\text { Nivolumab : iv, } 3 \\
\mathrm{mg} / \mathrm{kg} \text { on day } 1 \\
\text { and } 15 \text { of each } \\
\text { cycle. } \\
\text { Azacitidine : Dose } \\
\text { level } 1, \mathrm{NA} \text {. Dose } \\
\text { level } 2,60 \mathrm{mg} / \mathrm{m}^{2} \text {. } \\
\text { Dose level } 3,75 \\
\mathrm{mg} / \mathrm{m}^{2}\end{array}$ & 51 & OS & 03628209 & Recruiting \\
\hline $\begin{array}{l}\text { MASCT-I + PD1 } \\
\text { antibody + } \\
\text { Apatinib }\end{array}$ & 1 & $\begin{array}{l}\text { SYZ Cell } \\
\text { Therapy Co. } \\
\text { (China) }\end{array}$ & $\begin{array}{l}\text { Multiple Target Antigen } \\
\text { Stimulating Cell Therapy } \\
\text { (MASCT-I) combined with PD1 }\end{array}$ & - & 20 & OS & 04074564 & Recruiting \\
\hline
\end{tabular}




\begin{tabular}{|l|l|l|l|l|l|l|l|}
\hline & & & $\begin{array}{l}\text { and apatinib in the treatment of } \\
\text { tissue sarcoma }\end{array}$ & & & \\
\hline $\begin{array}{l}\text { Toripalimab } \\
\text { (anti-PD-1) }\end{array}$ & 1 & $\begin{array}{l}\text { Shanghai } \\
\text { Junshi } \\
\text { Bioscience } \\
\text { Co., Ltd. } \\
\text { (China) }\end{array}$ & $\begin{array}{l}\text { Safety, tolerability and } \\
\text { pharmacokinetics of an anti-PD- } \\
1 \text { monoclonal antibody in } \\
\text { subjects with advanced } \\
\text { malignancies }\end{array}$ & 258 & CS & 03474640 & Recruiting \\
\hline
\end{tabular}

OS : osteosarcoma ; CS : chondrosarcoma ; EWS : Ewing sarcoma : ${ }^{*}$ Metastatic Ewing sarcoma 


\section{Figure Legends}

Figure 1: Immune infiltrates in bone sarcomas. Bone sarcoma tissues are invaded by numerous immune cells resulting in a permissive environment facilitating tumor progression and metastasis. A) Main molecular protagonists involved in the dialog between cancer or antigen presenting cells and $\mathrm{T}$ lymphocytes. The final effect on $\mathrm{T}$ cell effectors is a balance between activation $(+)$ and repression signals. B) Macrophage infiltrate is composed by two main subsets: M1 macrophages with pro-tumor activities and M2 with anti-tumor activities. M2 susbet is predominant with high bone sarcoma and is associated with the metastatic process. Cell-cell communications. C) Cancer cells can communicate with NK cells thanks the expression of NKGD2L. The expression of a relative specific ligand by cancer is a the origin of development of specific engineered CAR T cells recognizing cancer cells in a MHC independent manner.

Figure 2: Main immunotherapeutic approaches proposed for bone sarcomas. Tumour cells develop specific strategies to bypass the immune system. In this context, the two main therapeutic approaches are based on: i) the targeting of pro-tumoral effectors including M2 macrophages and the molecules associated with immune checkpoints; ii) the stimulation of anti-tumoral effectors. N-BPs: nitrogen containing bisphosphonates, DC: dendritic cells; NK: natural killer cells. 
A

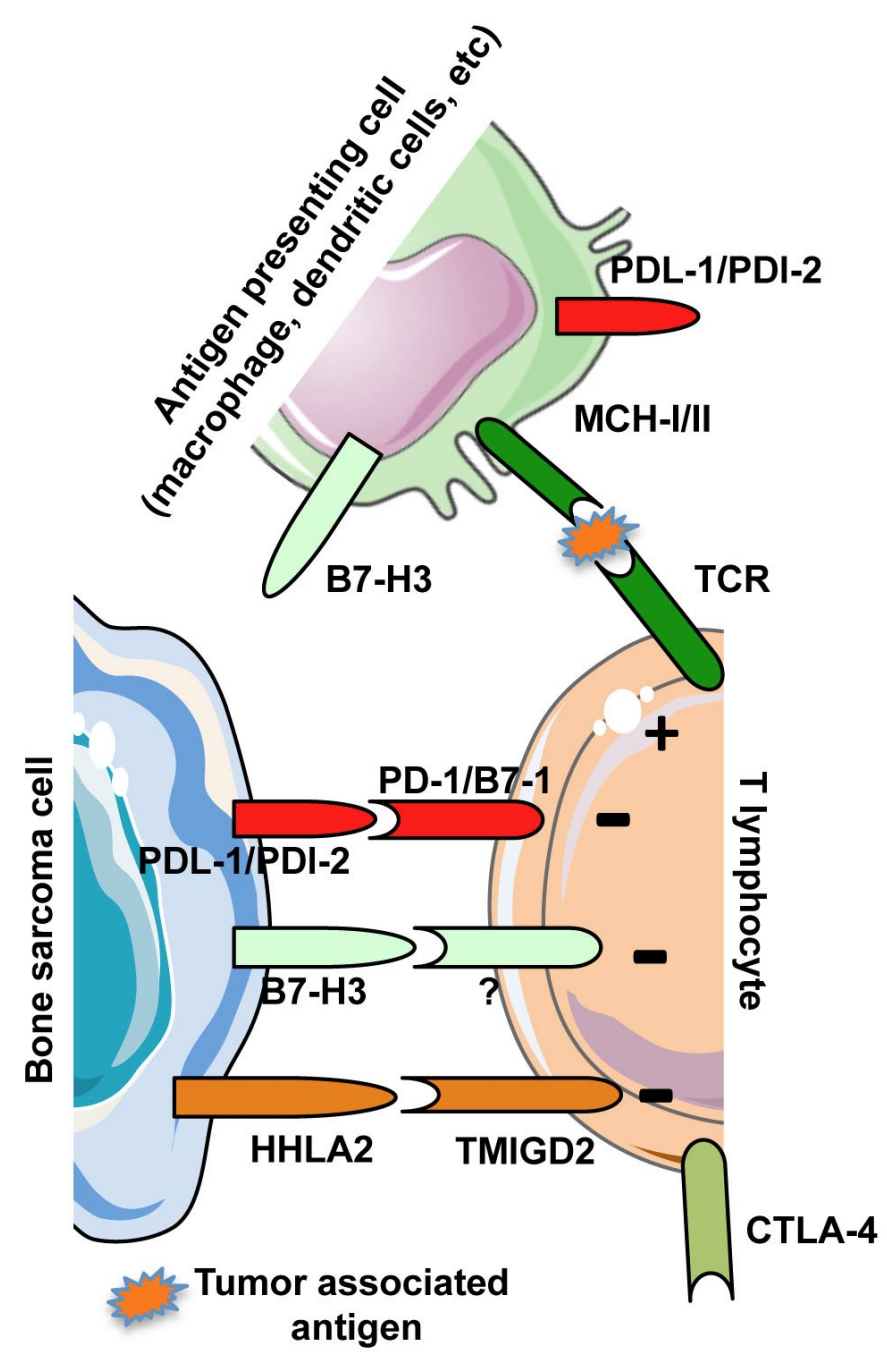

B

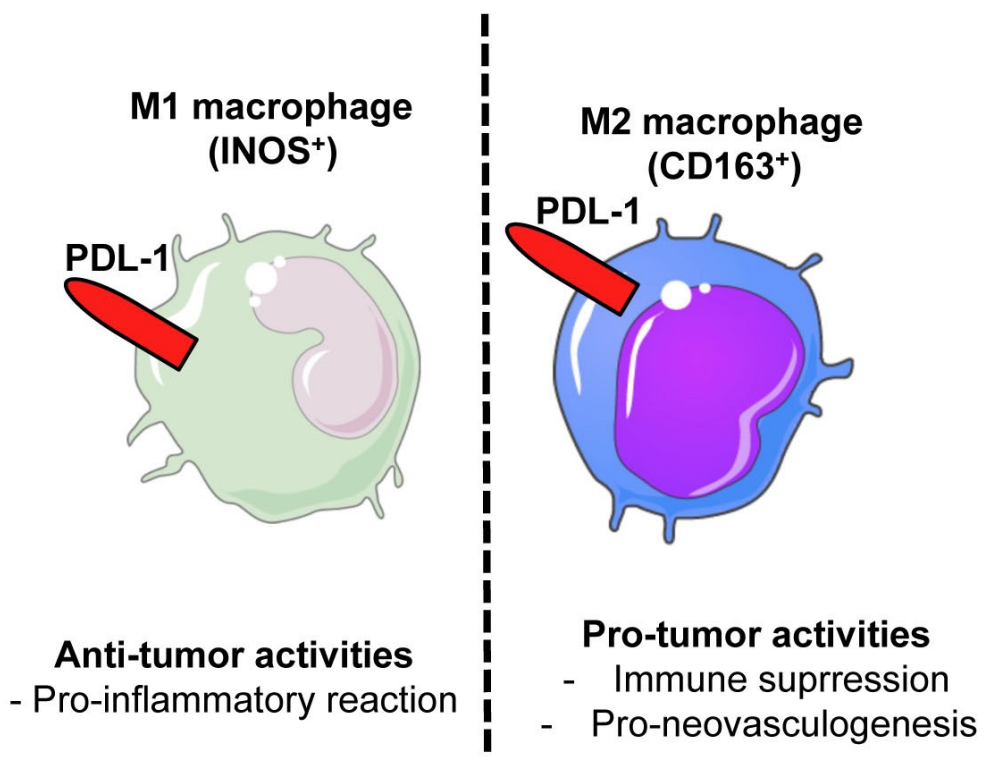

C

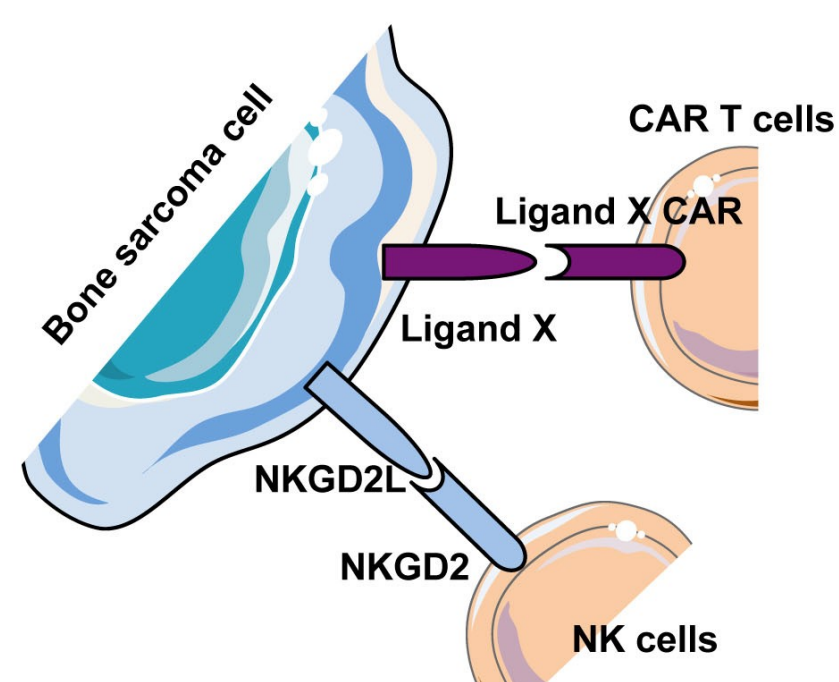


M2 macrophage depletion

Trabectedin

All-trans retinoic acid

Dihydroxycoumarins

IL-34 antagonists PD-1, PDL-1, CTLA-4

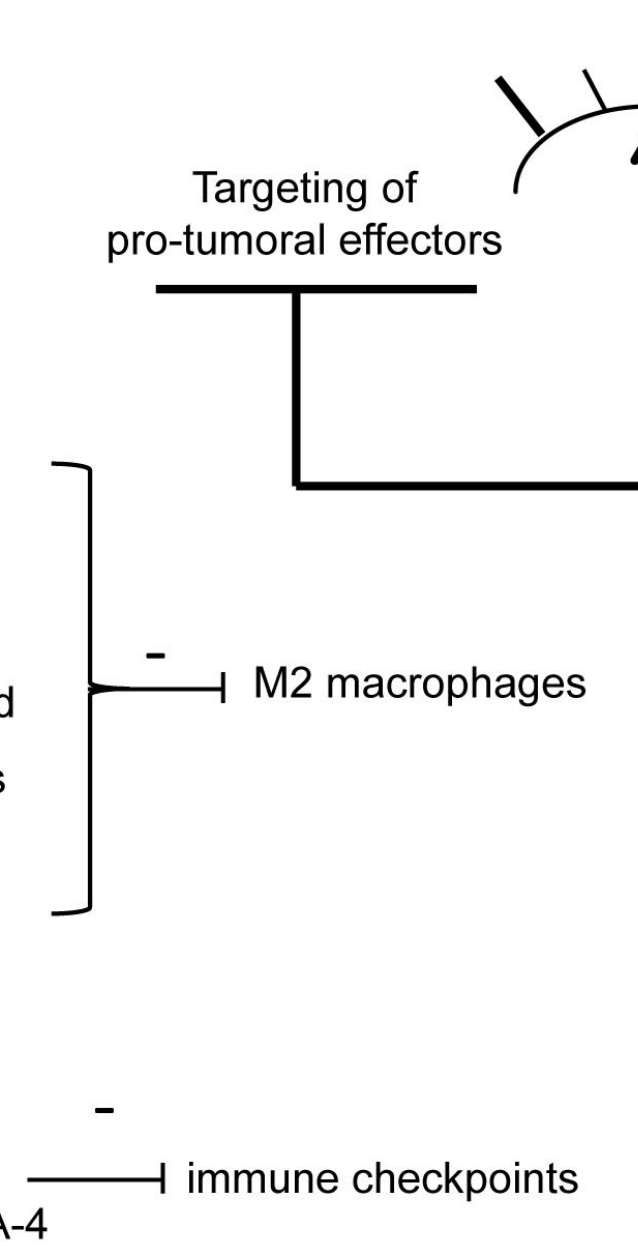

Cancer vaccine or adoptive $T$ cell therapies + $+/$ - combination with drugs (e.g. decitabine, N-BPs)

Targeting of anti-tumoral effectors

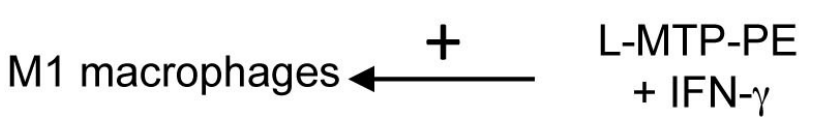

DC matured with autologous tumour lysate

DC pulsed with tumour associated antigens

T lymphocytes expressing

tumour associated antigens

$\gamma \delta$ T-lymphocytes

NK cells + IL-2

CAR T-cells

(BH-3, IGF-1, ROR1, IL-1, Folate

receptor, NKG2D/4-1BB/CD3z,

CD166/4-1BB, HER2, GD2, EGFR/CD19) 